\title{
The Synthesis of Hypodiphosphoric Acid and Derivatives with P-P Bond, including Esters and Diphosphine Dioxides: A Review
}

\author{
Jacek E. Nycz (1)
}

Citation: Nycz, J.E. The Synthesis of Hypodiphosphoric Acid and Derivatives with P-P Bond, including Esters and Diphosphine Dioxides: A Review. Molecules 2021, 26, 7286. https://doi.org/10.3390/ molecules26237286

Academic Editors: György Keglevich and Roman Dembinski

Received: 20 September 2021 Accepted: 27 November 2021 Published: 30 November 2021

Publisher's Note: MDPI stays neutral with regard to jurisdictional claims in published maps and institutional affiliations.

Copyright: (C) 2021 by the author. Licensee MDPI, Basel, Switzerland. This article is an open access article distributed under the terms and conditions of the Creative Commons Attribution (CC BY) license (https:// creativecommons.org/licenses/by/ $4.0 /)$.
Faculty of Science and Technology, Institute of Chemistry, University of Silesia in Katowice, ul. Szkolna 9, PL-40007 Katowice, Poland; jacek.nycz@us.edu.pl

\begin{abstract}
The synthesis of hypodiphosphoric acid and its related compounds began in 1877, but no summary of the synthetic efforts has been reported. This review includes published papers related to the molecules containing the $>\mathrm{P}(=\mathrm{O})-\mathrm{P}(=\mathrm{O})<$ fragment, which notably resembles the structure of the $>\mathrm{P}(=\mathrm{O})-\mathrm{O}-\mathrm{P}(=\mathrm{O})<$ moiety, the essential building block of many important molecules found in nature and in the field of medicinal chemistry. This review covers the strategies related to the synthesis of hypodiphosphoric acid (former name hypophosphoric acid), its ester form, and diphosphine dioxides. Finally, some properties and applications of these structures studied during this period are presented.
\end{abstract}

Keywords: hypodiphosphoric acid; hypodiphosphoric acid ester; diphosphine dioxide; biological activity; metal complex

\section{Introduction}

Many organophosphorus molecules are biologically active and have been widely used as pesticides in agriculture, anticancer drugs and antiviral agents in medicines, and anthelmintics in the veterinary field. Understanding the mechanism of their reaction or inhibition process is critical to shedding light on the design of more active and efficient compounds in terms of medicinal treatment and agricultural production. Organophosphorus compounds with $>\mathrm{P}(\mathrm{O})-\mathrm{O}-(\mathrm{O}) \mathrm{P}<$ structure have been extensively studied. Agents with $>\mathrm{P}(\mathrm{O})-(\mathrm{O}) \mathrm{P}<$ moiety bear the structure apparently resemble to $>\mathrm{P}(\mathrm{O})-\mathrm{O}-(\mathrm{O}) \mathrm{P}<$ type of compounds. However, their properties are quite different in terms of of resistance to hydrolysis. It is of interest to explore the impact of the structural similarity and difference on their synthetic pathway and potential applications. So far, only a few papers have been published using the $>\mathrm{P}(\mathrm{O})-(\mathrm{O}) \mathrm{P}<$ moieties to replace $>\mathrm{P}(\mathrm{O})-\mathrm{O}-(\mathrm{O}) \mathrm{P}<$ fragment in searching for potentially more effective inhibitors in metabolic routes [1,2], which were nonhydrolyzable analogs of compounds that possess $>\mathrm{P}(\mathrm{O})-\mathrm{O}-(\mathrm{O}) \mathrm{P}<$ moieties. A few other examples included mimicking nucleotides.

The phosphorus compounds possessing a P-P bond with $\mathrm{R}_{2} \mathrm{P}(\mathrm{O})-(\mathrm{O}) \mathrm{PR}_{2}$ type structure are called diphosphine dioxides $\left(\mathrm{R}=\right.$ Alkyl, Aryl), hypodiphosphoric acid $\left((\mathrm{HO})_{2} \mathrm{P}(\mathrm{O})\right.$ $(\mathrm{O}) \mathrm{P}(\mathrm{OH})_{2}$; former name hypophosphoric acid) or hypodiphosphoric acid esters $\left((\mathrm{RO})_{2} \mathrm{P}(\mathrm{O})\right.$ $\left.(\mathrm{O}) \mathrm{P}(\mathrm{OR})_{2}\right)$. There are only a few analog compounds published, i.e., hypodiphosphonates, in which both substituents on each phosphorus atom are different $((\mathrm{RO}) \mathrm{RP}(\mathrm{O})-(\mathrm{O}) \mathrm{PR}(\mathrm{OR}))$. All the mentioned molecules were insufficiently characterized in terms of spectroscopic characteristics and the procedure of synthesis, probably due to missing general synthetic methodologies, accompanying mechanisms, and/or some limitations in spectroscopic characterization. Other difficulties could be lacking proper structure elucidation for symmetric $>\mathrm{P}(\mathrm{O})-(\mathrm{O}) \mathrm{P}<$ type molecules, e.g., the ambiguity on the molecular formula of hypodiphosphoric acid $(\mathrm{HO})_{2} \mathrm{P}(\mathrm{O})-(\mathrm{O}) \mathrm{P}(\mathrm{OH})_{2}$. In contrast, the unsymmetrical $>\mathrm{P}_{A}(\mathrm{O})-(\mathrm{O}) \mathrm{P}_{\mathrm{B}}<\left(\mathrm{P}_{\mathrm{A}} \neq \mathrm{P}_{\mathrm{B}}\right)$ type compounds are much easier to distinguish due to two inequivalent phosphorus atoms, thanks 
to the characteristic large ${ }^{1} J_{P, P}$ coupling visible in ${ }^{31} \mathrm{P}\left\{{ }^{1} \mathrm{H}\right\}$ NMR spectra and ${ }^{\mathrm{n}} J_{\mathrm{P}, \mathrm{C}}$ couplings from both phosphorus atoms visible in $\left.{ }^{13} \mathrm{C}_{\{}{ }^{1} \mathrm{H}\right\}$ NMR spectra. Very interesting ${ }^{\mathrm{n}} J_{\mathrm{P}, \mathrm{H}}$ couplings from both phosphorus atoms cannot be omitted. The NMR spectroscopy can also be used to differentiate diastereoisomers from each other if they are present.

The present review is intended to comprehensively summarize recent advances in the process of $\mathrm{P}-\mathrm{P}$ bond formation in the $>\mathrm{P}(\mathrm{O})-(\mathrm{O}) \mathrm{P}<$ type compounds (Figure 1), highlighting plausible mechanistic considerations, defining the scope and limitations, and raising interest in these exciting molecules.<smiles>O=P(O)(O)P(=O)(O)O</smiles>

1<smiles>O=[PH](O)OP(=O)(O)O</smiles>

2<smiles>[R]OP([R6])(=O)P[R]</smiles>

6<smiles>[R]OP([R])O[Na]</smiles>

$7^{\prime}$<smiles>[R]OP(=O)(O[R])[PH]([R6])([R6])O[R]</smiles>
3<smiles>[R]P([R])(=O)[PH]([R])([R])[P+]([R])([R])[R]</smiles>

4
5<smiles>[R]OP([R])[R]</smiles>

8

8'<smiles>[R][R]([R])([R])[As]P([R])(=O)O</smiles>

\section{9}<smiles>[R]OP([R6])(=O)OP(=O)(O[R])O[R]</smiles>

10<smiles>[R]P([R])(=O)OP([R])([R])=O</smiles>

11<smiles>[R]OP([R20])OP([R6])([R])=O</smiles>

12<smiles>[R]P([R])OP([R])([R])=O</smiles>

13<smiles>[R]OP(O[R])OP([R6])[R]</smiles>

14<smiles>[R][R]([R])P([R])[R]</smiles>

18
$R^{2} P-O-P-R^{2}$

15<smiles>[R]P([R7])C</smiles>

20<smiles>[R][PH](=O)O</smiles>

16<smiles>[R][R]([R])=O</smiles>
16'<smiles>[R]OP([R])P([R6])([R])=O</smiles>

17

Figure 1. The general structures of presented molecules $\left(R=A l k y l\right.$, Aryl; $R^{1}=R$ or $R O ; R^{2}=R$ or $\mathrm{NR}_{2} ; \mathrm{Y}=\mathrm{NR}_{2}$ or TFA).

\section{Hypodiphosphoric Acid}

Hypodiphosphoric acid (1) has been known about since the end of the 19th century. In 1877, Salzer published a synthetic procedure for the production of hypodiphosphoric acid salts (1') (Scheme 1) [3-7].

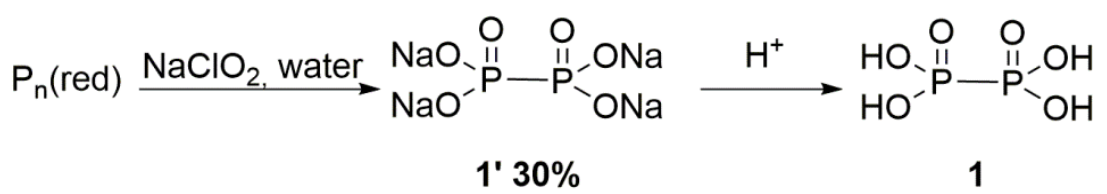

Scheme 1. The synthesis of hypodiphosphoric acid (1).

Until now, no mechanism has been established for the formation of hypodiphosphoric acid (1). Acid $\mathbf{1}$ is a white crystalline molecule, stable as a hydrated form at room temperature. In aqueous solutions molecule $\mathbf{1}$ behaves as a weak tetrabasic acid at $25^{\circ} \mathrm{C}\left(\mathrm{pKa}_{1}=2.2\right.$, $\left.\mathrm{pKa}_{2}=2.8, \mathrm{pKa}_{3}=7.3, \mathrm{pKa}_{4}=10.0\right)[8,9]$. The hypodiphosphates $\left(\mathbf{1}^{\prime}\right)$ undergo protonation to form compound $\mathbf{1}$ in strongly acidic aqueous solutions. However, acid $\mathbf{1}$ is unstable under acidic conditions and disproportionated to $\mathrm{H}_{3} \mathrm{PO}_{4}$ and $\mathrm{H}_{3} \mathrm{PO}_{3}[8,10]$. One explanation of the instability of molecule $\mathbf{1}$ is due to a slow rearrangement to unsymmetrical 
isohypodiphosphoric acid (2). In the composition of acid 2, the two phosphorus atoms in different oxidation states are connected via an oxygen atom (Scheme 2) [9].

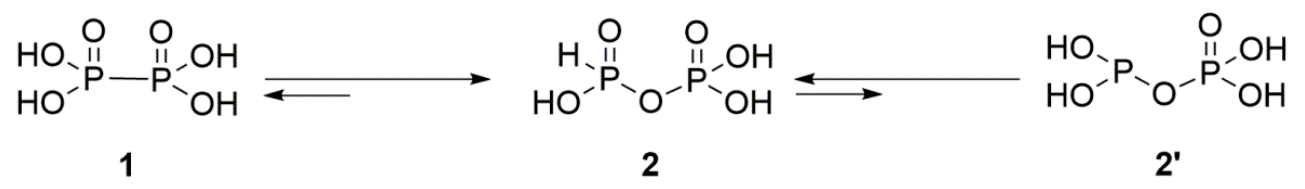

Scheme 2. The rearrangement of hypodiphosphoric acid (1) to isohypodiphosphoric acid (2).

The acid 2 is not stable and disproportionates to $\mathrm{H}_{4} \mathrm{P}_{2} \mathrm{O}_{7}$ and $\mathrm{H}_{4} \mathrm{P}_{2} \mathrm{O}_{5}$. An alternative explanation of its instability could be the tautomerism of isohypodiphosphoric (2) with mixed phosphorus anhydride tautomer ( $\left.2^{\prime}\right)$ (Scheme 2). The tautomeric equilibrium between the pentavalent central phosphorus atom in $>\mathrm{P}=(\mathrm{O})-\mathrm{H}$ type molecules and the trivalent phosphorus in phosphinous acids $\mathrm{R}_{2} \mathrm{P}-\mathrm{OH}$ is almost completely shifted to the side of the formation of a strong $\mathrm{P}=\mathrm{O}$ bond (Scheme 2 ). The only known example of a thermally stable phosphinous acid is bis(trifluoromethyl)phosphinous acid, $\left(\mathrm{CF}_{3}\right)_{2} \mathrm{P}-\mathrm{OH}$ [11], which was synthesized in 1960 by Burg and Griffiths [12]. Recently, Hoge et al. reported the solvent dependent tautomeric equilibrium between bis(pentafluorophenyl)phosphane oxide and the bis(pentafluorophenyl)phosphinous acid. The phosphinous acid is the dominated form in polar aprotic solvents, such as DMSO or DMF, but bis(pentafluorophenyl)phosphane oxide in toluene or $\mathrm{CHCl}_{3}$ [13].

In 1971, the structure of the acid 1 was determined by single-crystal X-ray diffraction measurements [14], followed by structures of alkali metals and heavy alkali-metals [15-28]. Structural analysis of molecule $\mathbf{1}^{\prime}$ with organic cations has been undertaken using the salts of protonated adenine [29].

Gjikaj and co-workers synthesized the rubidium and cesium salts of $\mathbf{1}^{\prime}$, the properties of which have been characterized by a combination of several techniques: FT-Raman and ${ }^{31} \mathrm{P}$ and ${ }^{1} \mathrm{H}$ MAS NMR [18]. They obtained the crystals of isotypic in the triclinic space group $P-1$ with one formula unit in the unit cell. The structures were built up by discrete $\left(\mathrm{H}_{2} \mathrm{P}_{2} \mathrm{O}_{6}\right)^{2-}$ and $\left(\mathrm{H}_{4} \mathrm{P}_{2} \mathrm{O}_{6}\right)$ units in a staggered conformation for the $\mathrm{P}_{2} \mathrm{O}_{6}$ skeleton and the corresponding alkali-metal cations. $\mathrm{X}$-ray structural analysis confirmed the reported structures, which showed $\mathrm{O} \bullet \bullet \bullet \mathrm{HO}-\mathrm{P}$ hydrogen bonds between the $\left(\mathrm{H}_{2} \mathrm{P}_{2} \mathrm{O}_{6}\right)^{2-}$ and $\left(\mathrm{H}_{4} \mathrm{P}_{2} \mathrm{O}_{6}\right)$ groups, consolidating the systems into a three-dimensional network. The

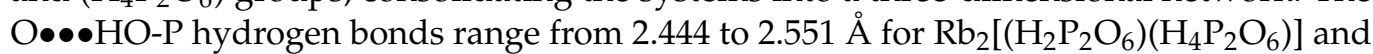
from 2.441 to $2.551 \AA$ for $\mathrm{Cs}_{2}\left[\left(\mathrm{H}_{2} \mathrm{P}_{2} \mathrm{O}_{6}\right)\left(\mathrm{H}_{4} \mathrm{P}_{2} \mathrm{O}_{6}\right)\right]$ molecule. The P-P distance is $2.175 \AA$ for $\mathrm{Rb}$ and $2.182 \AA$ for $\mathrm{Cs}$ salts, the $\mathrm{P}-\mathrm{O}$ bond lengths range from 1.501 to $1.569 \AA$, and both distances are consistent with the results of other works [13,16,24,30-32]. Emami et al. synthesized organic-inorganic salts of hypodiphosphoric acid tetraalkylammonium cations, which have been characterized by X-ray crystallography, IR spectroscopy, and NMR measurements in the solid state [30]. The ${ }^{31} \mathrm{P}\left\{{ }^{1} \mathrm{H}\right\}$ CPMAS NMR measurements showed that the $\mathrm{Na}_{4} \mathrm{P}_{2} \mathrm{O}_{6} \bullet 10 \mathrm{H}_{2} \mathrm{O}$ exhibits only one single resonance in $14.9 \mathrm{ppm}$, and for $\mathrm{Rb}$ salt at 12.5 and $13.5 \mathrm{ppm}$, and for Cs salt at 11.7 and $11.4 \mathrm{ppm}$. The ${ }^{1} \mathrm{H}$ MAS NMR spectra of $\mathrm{Rb}$ salt showed three well-resolved resonances signals at 16.1, 13.9, and $12.2 \mathrm{ppm}$, and for Cs salts at 16.1, 14.3, and $12.6 \mathrm{ppm}$. Based on the ${ }^{31} \mathrm{P}\left\{{ }^{1} \mathrm{H}\right\} \mathrm{CP}-\mathrm{HETCOR}$ spectrum of $\mathrm{Rb}$ salt, authors assigned the ${ }^{31} \mathrm{P}$ resonance at $13.5 \mathrm{ppm}$ to the dihydrogenhypodiphosphate anion and the resonance at $12.5 \mathrm{ppm}$ to the acid 1 moiety.

The acid $\mathbf{1}$ and its salts have attracted attention due to the discovery of the ferroelectricity properties of diammonium hypodiphosphate by Szklarz and co-workers [33,34]. Szklarz et al. reported the influence of the hydrogen bond for the ferroelectric phase transition shifts by about $20 \mathrm{~K}$ towards higher temperatures. They substituted hydrogen with deuterium in the molecule $\left(\mathrm{NH}_{4}\right)_{2} \mathrm{H}_{2} \mathrm{P}_{2} \mathrm{O}_{6}$, leading to compound $\left(\mathrm{ND}_{4}\right)_{2} \mathrm{D}_{2} \mathrm{P}_{2} \mathrm{O}_{6}$ [35]. 


\section{The Hypodiphosphoric Acid Esters}

The tetralkyl hypodiphosphoric acid esters (3) are known molecules and have been described in literature. However, no analog example with two aryloxy substituents on the pentavalent central phosphorus atom has been reported, especially with spectroscopic characterization. A possible explanation of the inaccessibility of the compounds is the impermanence of the P-O bond with the participation of aryloxy substituents [36]. It is important to mention that the related tetraalkyl hypodiphosphite with both trivalent phosphorus atoms is a unique compound, and tetraaryl hypodiphosphite is not reported in the literature. Even nowadays, we still lack efficient and predictable methods of synthesizing hypodiphosphoric acid esters (3) and related compounds. The current reported procedures are not generally practical and frequently suffer from drawbacks, such as low yields, tedious procedures, and lack of functionality tolerance (Scheme 3).

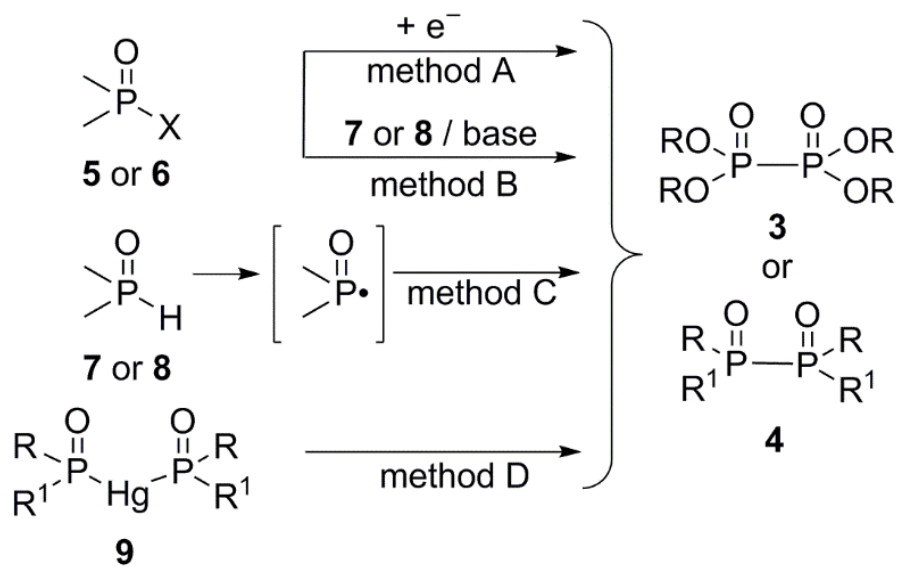

Scheme 3. Syntheses of the compounds 3 and $4\left(R^{1}=R\right.$ or $\left.R O\right)$. Method A: by the reduction of molecules 5 and $\mathbf{6}(\mathrm{X}=\mathrm{Cl}, \mathrm{Br}, \mathrm{I})$. Method $\mathrm{B}$ : by the reaction of electrophiles $\mathbf{5}$ and $\mathbf{6}$ with nucleophiles 7 and 8, respectively, in the presence of base $\mathrm{NaH}, \mathrm{Et}_{3} \mathrm{~N}, \mathrm{AlkylLi}$, ArylLi, etc. Method C: by the radical dimerization. Method D: decompositions of metal complexes 9.

Generally, there are four routes for the syntheses of compounds 3 that contain the $>\mathrm{P}(\mathrm{O})-(\mathrm{O}) \mathrm{P}<$ moiety (Scheme 3 ). One route relies on converting dialkyl phosphorohalidate (5) (mainly chlorides) by alkali metals in heterogeneous (alkali metals) or homogeneous conditions (e.g., potassium naphthalenide, or alkali metals in liquid ammonia) (method A). The reaction of the electrophiles $\mathbf{5}$ with alkali metals is a complex transformation, and the data presented in the literature are often incompatible. Baudler $[37,38]$ reported that the treatment of dialkyl phosphorochloridate $\mathbf{5}$ (formerly dialkyl chlorophosphate) with sodium in an inert solvent, such as xylene, toluene, or diethyl ether, at room temperature followed by gentle warming, resulted in a mixture of products consisting, in the main, of hypodiphosphoric acid esters (3) together with considerable amounts of anhydrides $\mathbf{1 0}$ (formerly pyrophosphoric acid esters). Similarly, the conversion of electron acceptors 5 by alkali metals in heterogeneous conditions often led to a complex reaction mixture [8]. This is not surprising because alkali metals can react with both starting material 5 and products (e.g., molecules 3 and 10), which are all electron acceptors [6].

Interestingly, method B presented in Scheme 3 relies on the conversion of dialkyl phosphonate 7 (formerly dialkylphosphite) with molecule 5 , which produces tetraalkyl hypodiphosphates 3, tetraalkyl diphosphates (10) (formerly tetraalkylpyrophosphates), and mixed anhydrides $12[39,40]$. Comparing the reaction mixtures from both methods A and $B$, many similarities could be found, especially between the relative rate of product formation and their distribution profile [10]. For both routes, the mixtures formed are relatively complex.

Stec and co-workers reacted 2-chloro-5,5-dimethyl-1,3,2-dioxaphosphinane 2-oxide (5a) with diethyl phosphonate (7a) in a benzene solution, in the presence of triethylamine 
(Scheme 4) [41]. Unexpectedly, they isolated only symmetric anhydride, namely $2,2^{\prime}-$ oxybis(5,5-dimethyl-1,3,2-dioxaphosphinane 2-oxide) (10a) with 82\% yield (Scheme 4). They did not identify the second possible symmetric anhydride tetraethyl diphosphite (14a). This fact is significant for the explanation of the reactivity discussed. The mixed anhydride 5,5-dimethyl-2-oxido-1,3,2-dioxaphosphinan-2-yl diethyl phosphite (12a) was possibly formed as an $O$-phosphorylated product in the first step. Next, nucleophile $7 \mathbf{a}$, in the presence of $\mathrm{Et}_{3} \mathrm{~N}$, produces ammonium salts of 2-hydroxy-5,5-dimethyl-1,3,2dioxaphosphinane 2-oxide (16a) as a leaving group, which in turn reacted with the electrophile 5a, giving symmetric anhydride 10a (Scheme 4).<smiles>CCOP(=O)(OCC)OCC</smiles>

$5 a$
$7 a$

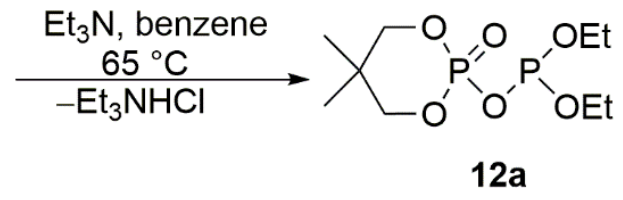

$7 a$<smiles>CC[CH+]OP(OCC)OP(OCC)OP(OCC)OCC</smiles>

$16 a^{\prime}$

$14 a ; 0 \%$

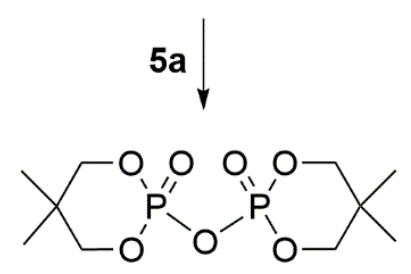

$10 a ; 82 \%$

Scheme 4. Reaction of 2-chloro-5,5-dimethyl-(1,3,2)-dioxaphosphinane-2-oxide (5a) with diethyl phosphonate (7a).

In another paper, the same group of authors conducted a reaction between electrophile $\mathbf{5 b}$ and nucleophile $\mathbf{7 a}$ in benzene solution in the presence of triethylamine (Scheme 5). They isolated as the main constituent molecule $10 \mathbf{b}$, contaminated with some amounts of anhydrides of phosphorus acids at different oxidation levels $\mathbf{1 2 b}$ and 14a. The authors claimed that compound 3a was not detected.

The authors in both experiments (Schemes 4 and 5) excluded the mixed anhydrides 12a or 12b as a key intermediate that could explain the presence of anhydrides 10a or 10b "oxidized" and 14a "reduced" with the absence of molecule 3a. It was found that under the conditions of the described reaction, the mixed anhydride $\mathbf{1 2 b}$ did not react with either nucleophile $7 \mathbf{a}$ in the presence of triethylamine at room temperature or electrophile 5a, which excluded its contribution to the reaction as an intermediate product, a precursor to the observed symmetric anhydrides $\mathbf{1 0}$ and $\mathbf{1 4}$. The authors claimed that in Scheme 5 the reaction went through the deoxygenation of diethyl phosphorochloridate (5b) by diethyl phosphonate (7a), which became diethyl hydrogen phosphate (16b). The acid $16 b$ could react with the diethyl phosphorochloridate $(5 b)$, giving the main product tetraethyl diphosphate (10b). On the other hand, the diethyl phosphonate (7a) could react with deoxygenated diethyl chlorophosphite (20a), giving symmetric three coordinated anhydride tetraethyl diphosphite (14a). The acid $\mathbf{1 6 b}$ could react with electrophile 20a, giving mixed anhydride 12b (Scheme 6). These researchers demonstrated that anhydrides $10 \mathrm{~b}$ and $14 \mathrm{a}$ were not the products of rearrangements of the originally arising anhydride 12b (Scheme 6). 


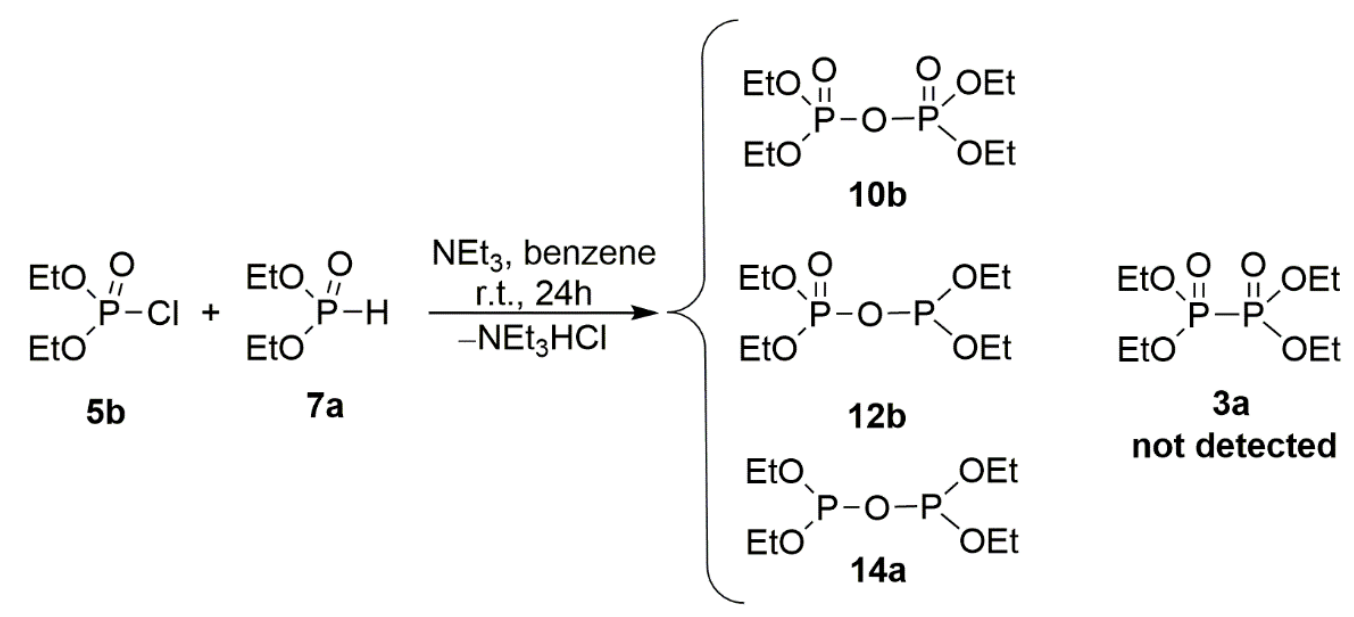

Scheme 5 . The reaction between electrophile $5 \mathbf{b}$ and nucleophile $7 \mathbf{a}$.
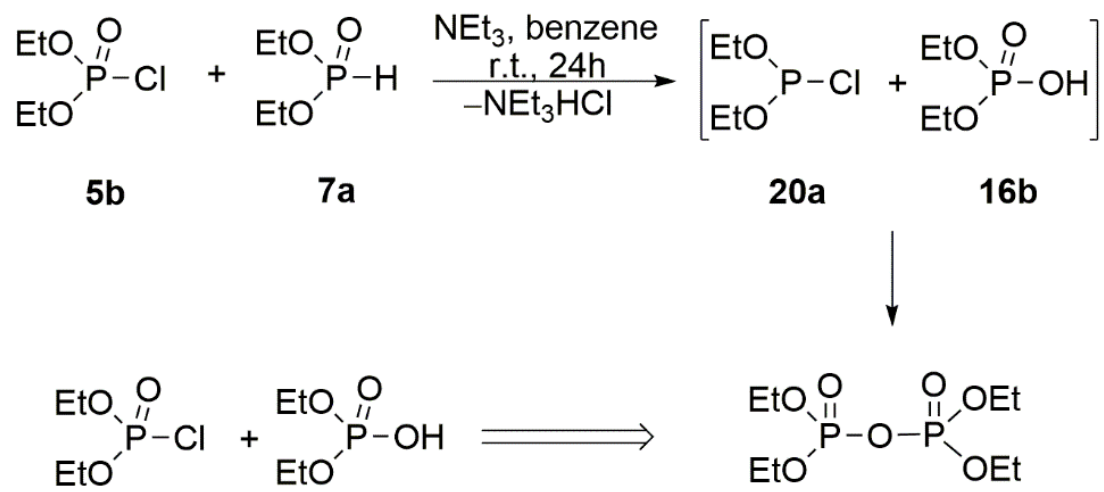

$5 b$

$16 b$
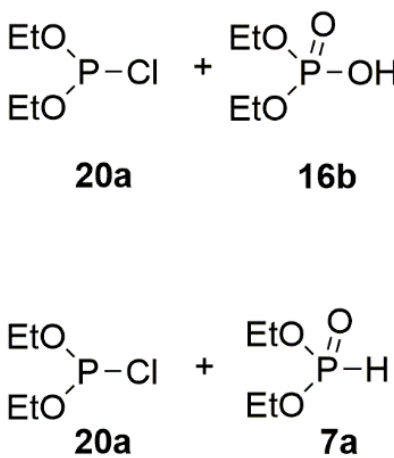

Scheme 6 . The possible reaction routes of the reaction between the electrophile $5 \mathbf{b}$ and nucleophile $\mathbf{7 a}$.

The $>\mathrm{P}^{-} \mathrm{O}^{-}$anion (the salts of molecules 7 and 8 ) is an ambident nucleophile having a hard centre on the oxygen and a soft one on the phosphorus atom. Accordingly, many examples can be indicated where such an anion reacted selectively, either via the phosphorus [42] or the oxygen [43], respectively (Scheme 7). 


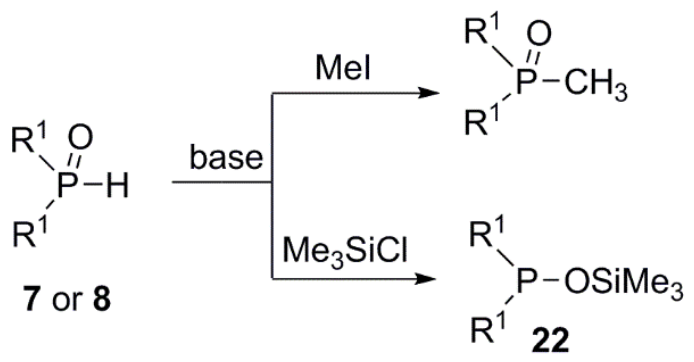

Scheme 7. The dual reactivity of nucleophiles 7 and $8\left(R^{1}=R\right.$ or $\left.R O\right)$.

Similar to the aforementioned reactivity, the ambident phosphorus nucleophiles 7 can react with phosphorus electrophiles 5 to produce both $P$-phosphorylated products, i.e., the tetraalkyl hypodiphosphoric acid esters 3, and O-phosphorylated products i.e., mixed anhydrides 12 (Scheme 8). The mixed anhydride 12 is a critical intermediate, explaining the formation of anhydrides $\mathbf{1 0}$ (Schemes 4 and 8). The pattern of the yield distribution depends on the substituent located on both phosphorus atoms (nucleophile and electrophile). The architecture of products 3 and 12, with the presence of single or double bonds between oxygen and phosphorus atoms, is controlled by steric and/or electronic factors of substituents $\mathrm{R}$ (Scheme 8). The reaction mixture analysis indicated that target products 3 were always accompanied by the "reduced" molecules 17 and/or 14 and "oxidized" compounds, resulting in anhydrides 10 (Scheme 8).

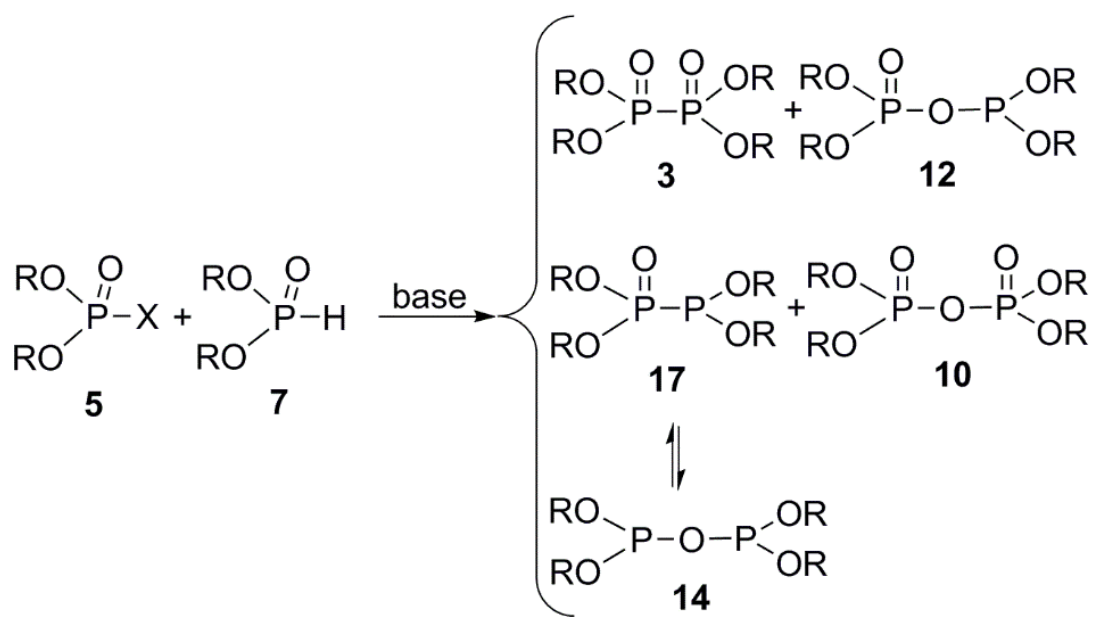

Scheme 8. The reaction between nucleophiles 7 and electrophiles 5 .

In 1966, Wall's team reported the results of an interesting reaction between 3-methyl5-(trichloromethyl)-1,2,4-oxadiazole and diethyl phosphonate (7a) in the presence of triethylamine in a diethyl ether environment [44]. The authors assumed that in the first step of the reaction, nucleophile $7 \mathbf{a}$ attacked the halogen of the trichloromethyl group of the 3-methyl-5-(trichloromethyl)-1,2,4-oxadiazole yielding dehalogenated 5-(dichloromethyl)3 -methyl-1,2,4-oxadiazole with $67 \%$ yield. The in situ generated electrophile diethyl phosphorochloridate $(\mathbf{5 b})$ further reacted with nucleophile $\mathbf{7 a}$, which was already presented in the reaction environment giving tetraethyl hypodiphosphate (3a) and tetraethyl diphosphate (10b) (Scheme 9). In the next experiment, the authors replaced diethyl ether with ethyl alcohol, increasing the synthesis efficiency of dehalogenated 5-(dichloromethyl)-3-methyl1,2,4-oxadiazole from $67 \%$ to $91 \%$ yield. The in situ generated electrophile $5 \mathrm{~b}$ reacted faster with ethanol than with molecule 7a. As a result, the nucleophile 7a in higher concentration reacted more efficiently with 3-methyl-5-(trichloromethyl)-1,2,4-oxadiazole. The products were isolated by vacuum distillation and identified by vapor phase chromatography. 


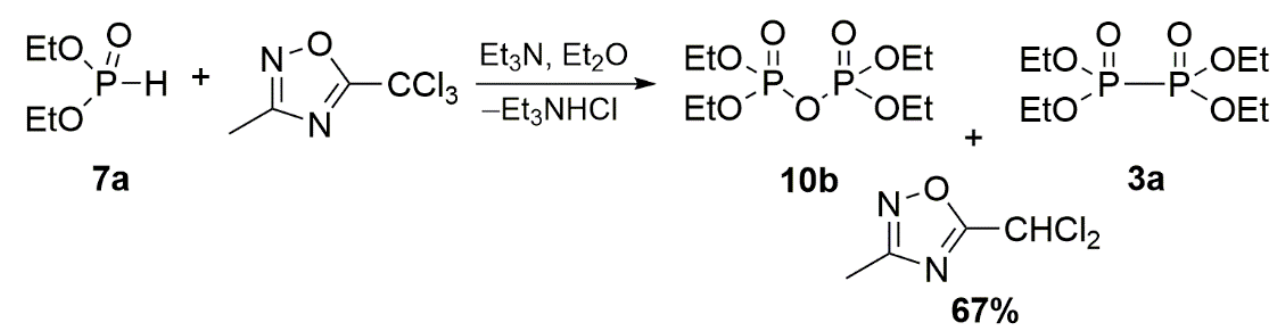

Scheme 9. The reaction between nucleophile 7a and 3-methyl-5-(trichloromethyl)-1,2,4-oxadiazole (no yields of $\mathbf{3 a}$ and $\mathbf{1 0 b}$ were given).

Steinberg conducted a chlorination reaction of diethyl phosphonate (7a) with $\mathrm{CCl}_{4}$ in the presence of triethylamine (Scheme 10) [45]. He found the formation of high-boiling by-products, which, based on the refractive index values, were assigned a composition of $83 \%$ tetraethyl diphosphate $(\mathbf{1 0 b})$ and $17 \%$ tetraethyl hypodiphosphate (3a). The product composition was similar to earlier work undertaken by Nylen [46].

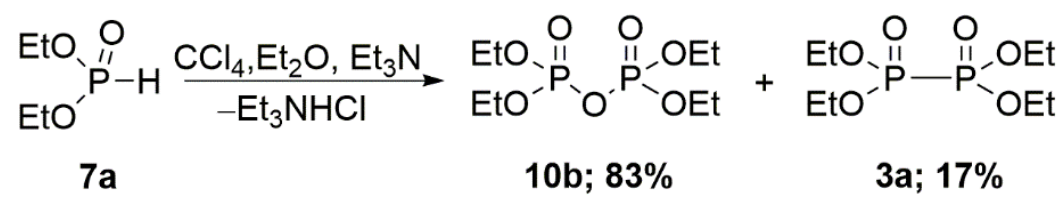

Scheme 10. The reaction between nucleophile $7 \mathbf{a}$ and $\mathrm{CCl}_{4}$.

In 1932, Arbuzov et al. treated phosphate anion $\mathbf{7 \mathbf { a } ^ { \prime }}$ with chlorine gas. In the first step of the reaction, a complex mixture of products was formed, which, after treatment with an excess of chlorine, turned into diethyl chlorophosphite (20a) (Scheme 11) [47].

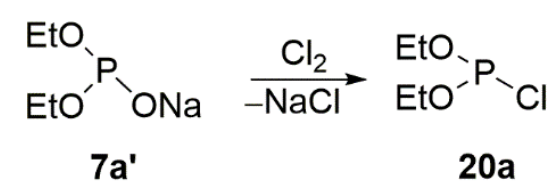

Scheme 11. The reaction between nucleophile $7 \mathbf{a}^{\prime}$ with chlorine gas (no yield was given).

Zwierzak et al. carried out a reaction of sodium salt of diethyl phosphonate $\left(7 \mathbf{a}^{\prime}\right)$ and diethyl phosphorochloridate (5b) [39]. The authors obtained nucleophile $\mathbf{7} \mathbf{a}^{\prime}$ through treating diethyl phosphonate ( $7 \mathbf{a}$ ) by metallic sodium. They noted that the use of $25 \%$ excess of nucleophilic reagent $7 \mathbf{a}^{\prime}$ avoided the formation of anhydride $10 \mathrm{~b}$. After the distillation of the reaction mixture, they obtained a forehead which, from a vigorous reaction with water, attributed to the mixed anhydride 12b, and the main fraction, based on the refractive coefficient considered to be a mixture of molecule $\mathbf{3 a}$ and anhydride $\mathbf{1 2} \mathbf{b}$ in a ratio of approximately 5:1 (Scheme 12).

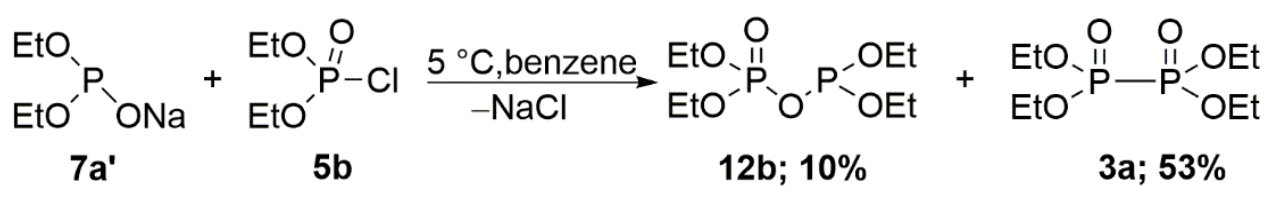

Scheme 12. The reaction between nucleophile $7 \mathbf{a}^{\prime}$ and diethyl phosphorochloridate (5b).

Zwierzak's team reported the efficient synthesis of mixed anhydrides $\mathbf{1 2}$ based on the reaction of dialkyl phosphonate $\mathbf{7}$ with dialkyl phosphorochloridate 5 in benzene, in the presence of pyridine (reaction A; Scheme 13) [48]. The products were purified by vacuum distillation. The authors mentioned that they were unable to purify mixed anhydrides $\mathbf{1 2 g}$. 
From the present perspective, the likely explanation of this difficulty is the existence of mixed anhydrides $\mathbf{1 2 c}, \mathbf{1 2 d}$, and $\mathbf{1 2} \mathrm{g}$ as diastereoisomeric mixtures (meso and rac) among the products (reaction A; Scheme 13).

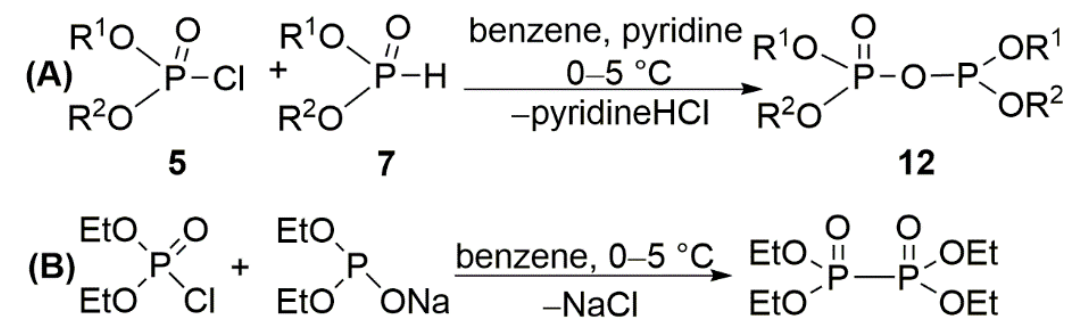

5b 7 a'; $50 \%$ excess $3 a ; 53 \%$

\begin{tabular}{cccc}
\hline $\mathbf{1 2 .}$ & $\mathbf{R}^{\mathbf{1}}$ & $\mathbf{R}^{\mathbf{2}}$ & Yield (\%) \\
\hline $\mathbf{1 2 b}$ & $\mathrm{Et}$ & $\mathrm{Et}$ & 70 \\
$\mathbf{1 2 c}$ & $\mathrm{Pr}^{\mathrm{n}}$ & $\mathrm{Et}$ & 77 \\
$\mathbf{1 2 d}$ & $\mathrm{Pr}^{\mathrm{n}}$ & $\mathrm{Bu}^{\mathrm{n}}$ & 78 \\
$\mathbf{1 2 e}$ & $\mathrm{Pr}^{\mathrm{i}}$ & $\mathrm{Pr}^{\mathrm{i}}$ & 53 \\
$\mathbf{1 2 f}$ & $\mathrm{Bu}^{\mathrm{n}}$ & $\mathrm{Bu}^{\mathrm{n}}$ & 70 \\
$\mathbf{1 2} \mathrm{g}$ & $\mathrm{PhCH}_{2}$ & $\mathrm{Et}$ & $88^{*}$ \\
\hline
\end{tabular}

Scheme 13. The reaction between nucleophile 7 and electrophile 5 ( ${ }^{*}$ crude product $\left.\mathrm{nr} . \mathbf{1 2} \mathrm{g}\right)$.

Three years later, in a brief communication, the same group of authors reported the synthesis of tetraethyl hypodiphosphate (3a) with a yield of 53\% [49]. They reacted sodium salts of diethyl phosphonate $\left(7 \mathbf{a}^{\prime}\right)(50 \%$ excess) with diethyl phosphorochloridate (5a) in benzene solution at $0-5{ }^{\circ} \mathrm{C}$ (reaction B; Scheme 13). The product was isolated by distillation in vacuo and finally characterized by Raman spectroscopy. The characteristic frequency of the P-P bond was observed at $257 \mathrm{~cm}^{-1}$. Additionally, the authors realized that the esterification of anhydrous hypodiphosphoric acid (1) by diazoalkanes as an alternative procedure was unsuitable because of the poor accessibility of anhydrous acid $\mathbf{1}$.

In a subsequent publication, Zwierzak et al. reported the syntheses of cyclic derivatives of tetralkyl hypodiphosphoric acid ester 3 and its sulfur analogs and related compounds. They mentioned that their cyclic molecules were more stable than acyclic analogs [40]. The described procedure was based on previously reported syntheses of acyclic analogs [49]. They reacted $50 \%$ excess of sodium salts of cyclic 5,5-dimethyl-1,3,2-dioxaphosphinane 2-oxide (7b) with cyclic 2-chloro-5,5-dimethyl-1,3,2-dioxaphosphinane 2-oxide (5a) in benzene solution at $5-10{ }^{\circ} \mathrm{C}$, and anhydride 10a was not isolated (Scheme 14) [40]. For equimolar proportions of used reagents $7 \mathbf{b}^{\prime}$ and $5 \mathbf{a}$, the yield of product $3 \mathbf{b}$ decreased to $27 \%$, and small amounts $(6 \%)$ of anhydride 10a were isolated.

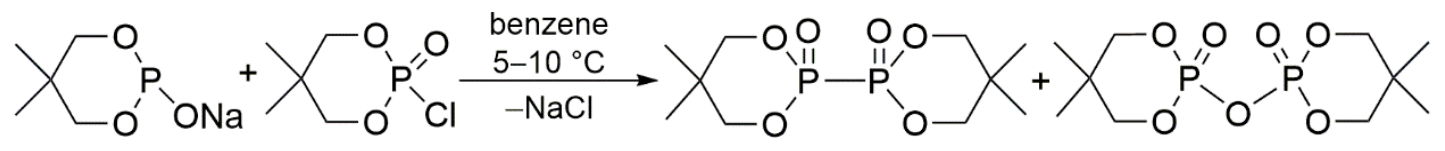

$7 b^{\prime}$

$7 b^{\prime} 50 \%$ excess
$5 a$
$3 b ; 27 \%$

$3 b ; 40 \%$ 10a; $6 \%$

$10 \mathrm{a} ; 0 \%$

Scheme 14. The reaction between nucleophile $\mathbf{7 \mathbf { a } ^ { \prime }}$ and electrophile $\mathbf{5 a}$.

All yields were referred to products isolated by crystallization and identified by chemical properties, IR spectra, and elemental analysis. The authors compared the stability of acyclic tetralkyl hypodiphosphoric acid esters $\mathbf{3}$ with obtained molecule $\mathbf{3} \mathbf{b}$, and found 
that the acyclic molecules were relatively easily hydrolyzed compared to cyclic $3 \mathbf{b}$, which remained almost intact when refluxed with water in tetrahydrofuran solution for $20 \mathrm{~h}$.

Mehrotra et al. reported the syntheses of unsymmetric hypodiphosphoric acid esters i.e., diisopropyl dipropyl hypodiphosphate (3c), which was obtained in the reaction of diisopropyl phosphorochloridate (5c) with the diesters of phosphonic acids activated by the 1,3,2-dioxarsolan moiety $\left((\mathrm{RO})_{2} \mathrm{P}(\mathrm{O})-\mathrm{As}\left(\mathrm{OCH}_{2}\right)_{2}\right)$ [50]. Unfortunately, the authors did not present either the synthesis procedure or the characteristics of the resulting products.

Zhao's team used dialkyl phosphonates $5\left(\mathrm{Alkyl}=\mathrm{Me}, \mathrm{Et}, \mathrm{Pr}^{\mathrm{i}}\right)$ in the presence of $\mathrm{CCl}_{4}$ and triethylamine to synthesize $N$-phosphorylated amino acids and dipeptides [51]. In examining this reaction, they carried out a blank test, i.e., the chlorination of phosphorus nucleophiles 7 in the absence of $N$-nucleophile. However, in the reaction mixture, in addition to the expected dialkyl phosphorochloridates 5, they observed tetraalkyl diphosphate 10 anhydrides. The reaction presented here is similar to the presented above in Scheme 10 by Steinberg [45]. The yields of products $\mathbf{5}$ and $\mathbf{1 0}$ depended on substitutes located on phosphorus atoms.

Rachon et al. demonstrated the reduction of mixed anhydride 1,3-di-tert-butyl-1,3diphenyldiphosphoxane 1-oxide (mixture of meso and rac) $\mathbf{1 3 a}, \mathbf{b}$ to acid anion $\mathbf{1 6} \mathbf{c}^{\prime}$ and tertbutyl(phenyl)phosphido anion 19a' [43]. The obtained intermediates were subsequently treated by sulfur and methyl iodide. The final products tert-butyl(phenyl)phosphinic acid (16c) and methyl tert-butyl(phenyl)phosphinodithioate were isolated with good yields (Scheme 15). The presented cleavage is unequivocal and shows that the acid anion $\mathbf{1 6 c}^{\prime}$ is a good leaving group.

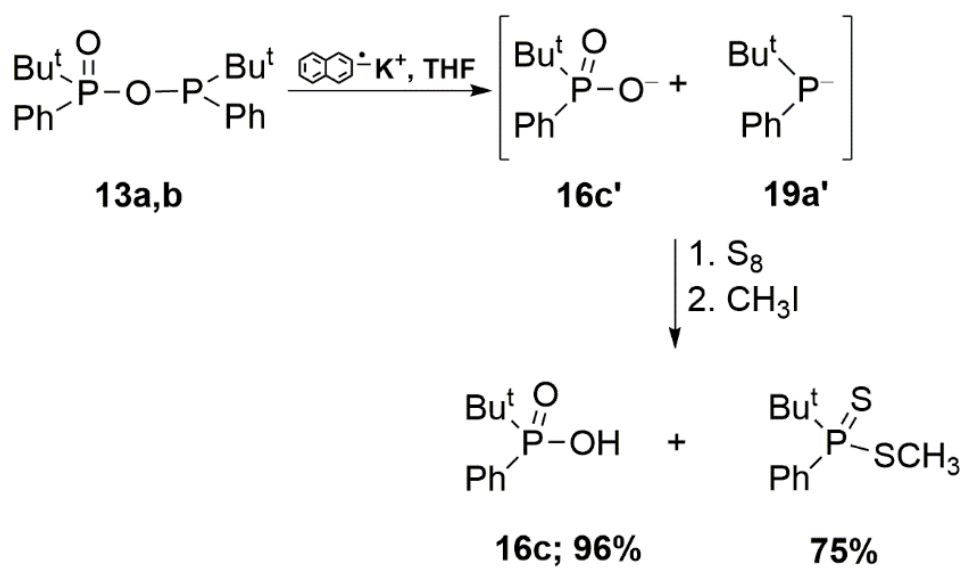

Scheme 15. Reduction of mixed anhydrides $\mathbf{1 3 a} \mathbf{a}, \mathbf{b}$.

The beginning of this section results from a reduction of dialkyl phosphorohalidate (5) by alkali metals in heterogeneous (alkali metals) or homogeneous conditions (e.g., potassium naphthalenide or alkali metals in liquid ammonia) were presented (method A; Scheme 3). The above results showed that mixed anhydrides 12 can be successfully reduced, and the reduction products were acid anion $\mathbf{1 6 \mathbf { c } ^ { \prime }}$ and tert-butyl(phenyl)phosphido anion 19a' (Scheme 15). Their presence can explain alternatively the mysterious origin of "oxidized" and "reduced" anhydrides 10 and 14, respectively, during the synthesis of molecules 3, which will be further explained.

The reactivity of ambident nucleophiles 7 is much less predictable than nucleophiles 19, having only one center on the phosphorus atom. The $>\mathrm{P}^{-\mathrm{O}^{-}} 7^{\prime}$ nucleophilicity depends on the type of substituents located on the phosphorus atom. It is assumed that alkoxy, aryloxy substituents directly connected to phosphorus atoms, should increase their nucleophilicity because they are $\alpha$-nucleophiles. The alpha effect is the interaction of the two lone pairs on adjacent oxygen atoms raises the HOMO of the anions and makes them better and softer nucleophiles. 


\section{The Isomerism between Molecules Possess $>\mathrm{P}(=\mathrm{O})-\mathrm{P}<$ and $>\mathrm{P}-\mathrm{O}-\mathrm{P}<$ Fragments}

To understand the possibilities and predictability of the syntheses of hypodiphosphoric acid 1, their esters 3 , diphosphine dioxides 4 , and related compounds 4 with P-P bond, it is necessary to know which substituents stabilize the structure of $>\mathrm{P}(\mathrm{O})-(\mathrm{O}) \mathrm{P}<$ type molecules. The best models for such a study are anhydrides 14,15 , and their isomers 17 and 18, respectively.

Anderson's team provided evidence that the diethyl phosphonate (7a) gave only $O$-phosphorylated products [52]. They developed the synthesis of tetraethyl diphosphite (14a) in a clean and fast (15 min) procedure. The obtained anhydride 14a with trivalent phosphorus atoms is a stable compound that was not transformed into isomeric diethyl (diethoxyphosphaneyl)phosphonate (17a) (Scheme 16).

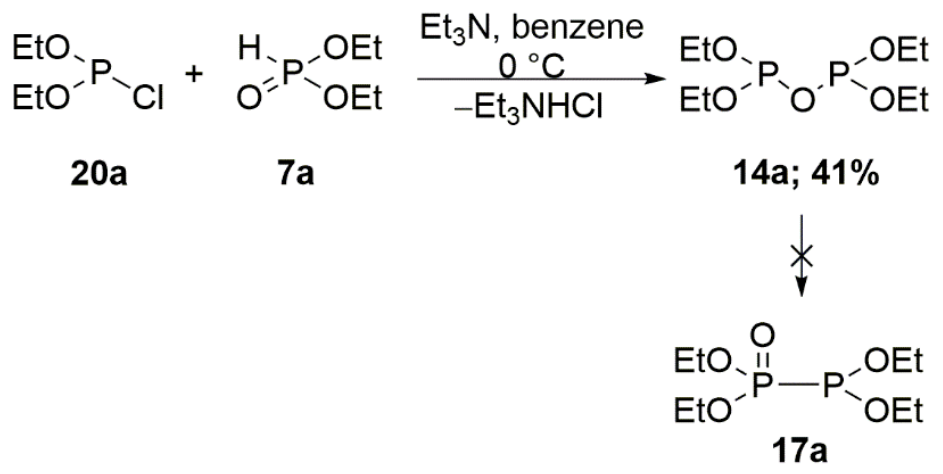

Scheme 16. The synthesis of tetraethyl diphosphite (14a).

Understanding the equilibrium between anhydride 14a and molecule 17a (Scheme 16) and their origin is the key to predict the efficiency of the synthesis of hypodiphosphoric acid esters 3, diphosphine dioxides 4, and related compounds 4 with P-P bond.

Anderson et al. obtained a stable unsymmetrical anhydride with trivalent phosphorus atom, namely 1,3,2-dioxaphospholan-2-yl diethyl phosphite (14b) [53]. The authors did not observe any isomerization processes which could produce molecule $\mathbf{1 7 b}$ or symmetrization transformations leading to symmetrical anhydrides 14a or 14c with identical substituents on both phosphorus atoms (Scheme 17).<smiles>CCOP[PH](=O)OCC</smiles>

$20 \mathrm{~b}$

$7 a$

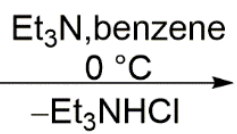<smiles>CCOP(OCC)OP1OCCO1</smiles>

14b 55\%<smiles>CCOP(=O)(OCC)P1OCCO1</smiles>

$17 b$<smiles>CCOP(OCC)OP(OCC)OCC</smiles>
$14 a$<smiles>C1COP([P-]P2OCCO2)O1</smiles>

14c

Scheme 17. The synthesis of 1,3,2-dioxaphospholan-2-yl diethyl phosphite (14b).

Crofts' team synthesized a stable anhydride, 2,2'-oxybis(2,3-dihydro- $1 H$-isophosphindole) (15a) (Scheme 18) [54]. 


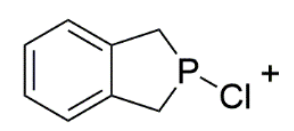

20c<smiles>O=[PH]1Cc2ccccc2C1</smiles>

$8 a$
$\mathrm{Et}_{3} \mathrm{~N}, \mathrm{Et}_{2} \mathrm{O}$

reflux, 2.5h

$-\mathrm{Et}_{3} \mathrm{NHCl}$<smiles>c1ccc2c(c1)CP(OP1Cc3ccccc3C1)C2</smiles>

$15 a ; 72 \%$

Scheme 18. The synthesis of 2,2'-oxybis(2,3-dihydro- $1 H$-isophosphindole) (15a).

Arbuzov et al. obtained nineteen symmetrical and unsymmetrical anhydrides $\mathbf{1 4}$ in the reaction between cyclic dialkyl chlorophosphite $\mathbf{2 0}$ and cyclic and non-cyclic sodium salts of dialkyl phosphonates $7^{\prime}$ (Scheme 19) [55]. The efficiency after the isolation was $20-69 \%$ yield, depending on the construction of both reactants.

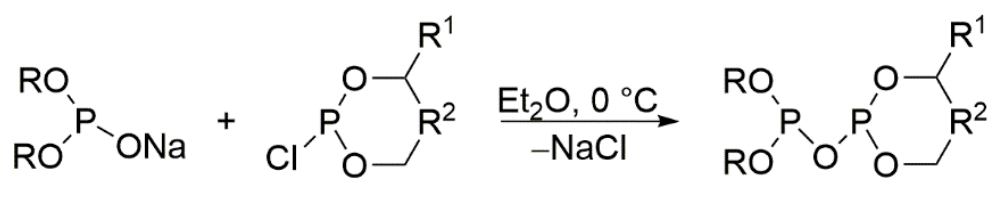

$7^{\prime}$<smiles>[R]C1OCOP(O[Na])O1</smiles>
$7^{\prime}$<smiles>[R]C1[R]COP(Cl)O1</smiles>

20
$14 ; 20-69 \%$<smiles>[R]C([R])OP1OCOC([R])CO1</smiles>

$14 ; 35-44 \%$

Scheme 19. The syntheses of anhydrides 14. $\mathrm{R}=\mathrm{Et}, \mathrm{Pr}, \mathrm{Pr}^{\mathrm{i}}, \mathrm{nBu} ; \mathrm{R}^{1}=\mathrm{H}, \mathrm{CH}_{3}, \mathrm{CH}_{2} \mathrm{Cl} ; \mathrm{R}^{2}=0, \mathrm{CH}_{2}$.

Foss et al., in 1980, conducted a series of reactions between metal salts of dialkyl phosphonates $7^{\prime}$ and phosphorus electrophiles 20 (Scheme 20) [56]. For the first time, they used reagents with dialkylamino substituents on phosphorus atoms and identified molecules 18 as the final products of this reaction (Method A, Scheme 20). However, when a nucleophile was used, which was generated in the reaction between molecules 8 and triethylamine, not only were the compounds $\mathbf{1 8}$ isolated, but anhydrides $\mathbf{1 5}$ were also obtained (Method B, Scheme 20).

(A)
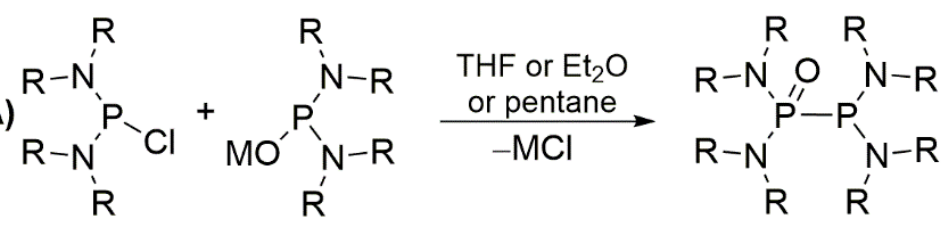

20

$8^{\prime}$

18<smiles></smiles>

20

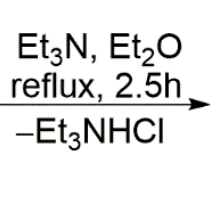

8

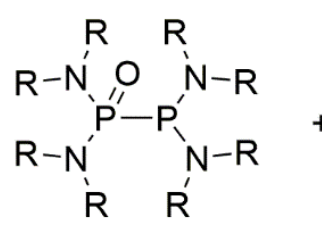

18<smiles>[R]N([R])P(OP(N([R])[R])N([R])[R])N([R])[R]</smiles>

15

Scheme 20. The syntheses of molecules $18\left(\mathrm{R}=\mathrm{Me}, \mathrm{Et}, \operatorname{Pr}, \operatorname{Pr}^{\mathrm{i}}\right.$ and $\mathrm{NR}_{2}=$ morpholine; $\mathrm{M}=\mathrm{Li}, \mathrm{Na}$ and Mg). Method A: (Me 68\%, Et 68\%, morpholine 0\% yields, respectively), Method B: (Et 68\%, Pr $64 \%, \operatorname{Pr}^{\mathrm{i}} 44 \%$ yields, respectively). 
These researchers concluded that molecules 18 were the primary products, which were subsequently isomerized into the anhydrides $\mathbf{1 5}$ and back. It was found that the rise of temperature increased the concentration of anhydrides 15. These molecules are easy to be distinguished from each other. The molecules 18 possess characteristic large ${ }^{1} J_{\mathrm{PP}}$ couplings in 125-290 Hz due to inequivalent phosphorus atoms. The symmetric anhydrides $\mathbf{1 5}$ (both phosphorus atoms are the same) were identified based on the singlets. In another work, the same team studied reactions in which one substrate had alkoxy residues, and the other had dialkylamino (Scheme 21) [57]. Nucleophilic reagents were generated in the reaction with triethylamine. The authors observed a complicated reaction mixture composed of monoxides in which both substituents on each phosphorus atom are different (e.g., 18a) and the same (e.g., 18b) molecules 18 and anhydrides 15. They explained the symmetrization process by the direct reaction of anhydrides 15 with electrophile $20 \mathrm{~d}$.

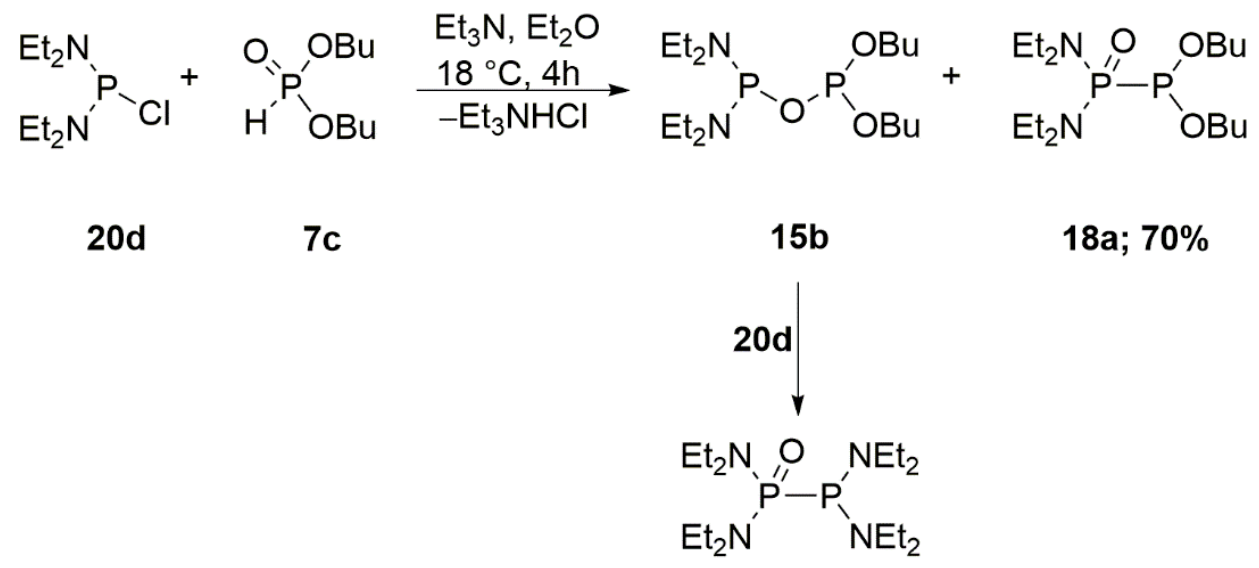

$18 b ; 84 \%$

Scheme 21. The synthesis of molecules $18 a$ and $\mathbf{1 8 b}$.

These researchers also dealt with another interesting experiment, where the trivalent anhydride tetrabutyl diphosphite (14d) was reacted with $N, N, N^{\prime}, N^{\prime}, N^{\prime \prime}, N^{\prime \prime}$-hexaethylphos phanetriamine in a clean procedure, giving dibutyl (bis(diethylamino)phosphaneyl)phospho nate (18c) (Scheme 22).

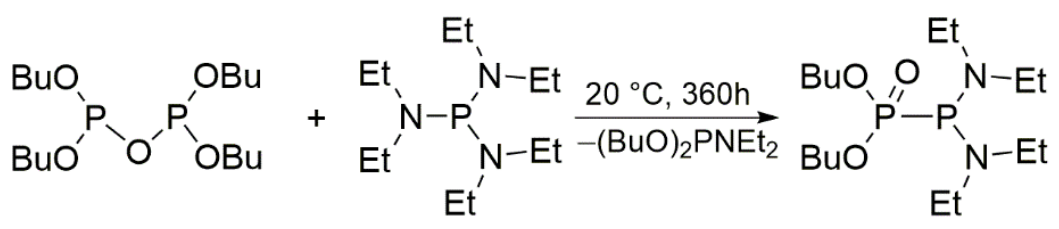

$14 d$

$18 \mathrm{c} ; 50 \%$

Scheme 22. The synthesis of molecule 18c.

In 1984, the same team discussed the possibility of equilibrium between molecules 18 and 15 [58]. At the temperature of $-78^{\circ} \mathrm{C}$, compounds 18 were formed, while anhydrides 15 were formed when a reaction was conducted under thermodynamic control. In this case, the nucleophile was generated by reacting molecule 8 with triethylamine at room temperature. Similar to previous research, the authors observed isomerization processes giving a complicated reaction mixture composed of symmetric and unsymmetric molecules 18 and anhydrides 15 [57]. This was confirmed by the fact that molecules 18 spontaneously isomerized into anhydrides 15, which were more thermodynamically stable [59]. In 1983, the same team in another paper described two reactions of a new type of the trivalent phosphorus electrophile, i.e., mixed anhydride $\mathbf{2 1 a}$, with nucleophiles $\mathbf{7 d}$ and $\mathbf{7 e}$, respectively [60]. The researchers received stable symmetric 14e and unsymmetric $14 \mathbf{f}$ anhydrides, 
which did not isomerize into appropriate molecules $\mathbf{1 7}$ (Scheme 23). It is important to mention that 2-((4-methyl-1,3,2-dioxaphospholan-2-yl)oxy)benzo[d][1-3]dioxaphosphole (14f) did not symmetrize.<smiles>O=C(OP1Oc2ccccc2O1)C(F)(F)F</smiles>

$21 a$<smiles>O=C(OP1Oc2ccccc2O1)C(F)(F)F</smiles>

21a<smiles>O=[PH]1Oc2ccccc2O1</smiles>
7d

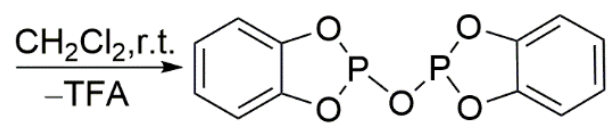

$14 \mathrm{e} ; 73 \%$
$\overrightarrow{-T F A}$<smiles>CC1COP(OP2Oc3ccccc3O2)O1</smiles>

$14 f ; 41 \%$

Scheme 23. The syntheses of molecules 14e and $14 \mathrm{f}$.

A few years later, Alfonsov et al. reported an interesting reaction between diethyl (trimethylsilyl) phosphite (22a) and diethyl phosphorochloridodithioite (20e) (Scheme 24). The authors chose silylated phosphorus nucleophiles $\mathbf{2 2}$, and isolated stable compounds $\mathbf{1 8}$ with good yields in the range of $44-60 \%$. The reported molecules 18 possessed characteristic large ${ }^{1} J_{\mathrm{PP}}$ couplings, ${ }^{1} J_{\mathrm{PP}}=189 \mathrm{~Hz}$ for $\mathrm{R}=\mathrm{EtO}$ and ${ }^{1} J_{\mathrm{PP}}=163 \mathrm{~Hz}$ for $\mathrm{R}=\mathrm{Me}_{3} \mathrm{SiO}$ [61]. Isomeric anhydrides $\mathbf{1 5}$ was not observed.

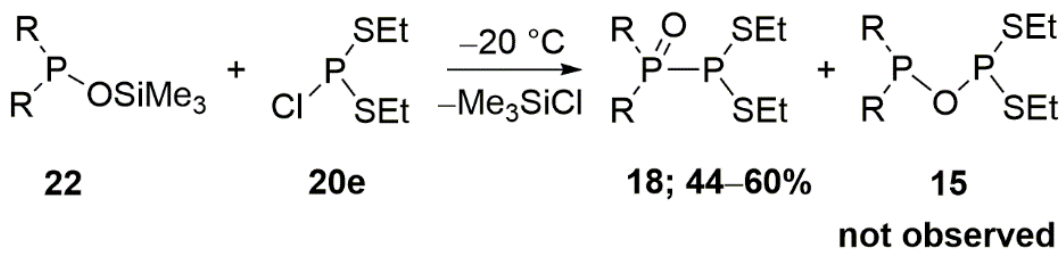

Scheme 24. The syntheses of molecules 18.

Nifantev et al. studied the reaction of cyclic phosphorus reagents 4,6-di-tert-butylbenz o[d][1-3]dioxaphosphole 2-oxide (7f) and 4,6-di-tert-butyl-2-chlorobenzo[d][1-3]dioxaphosp hole (20f) in the presence of triethylamine, in which only the sTable 2,2'-oxybis(4,6-di-tertbutylbenzo[ $d][1-3]$ dioxaphosphole) (14g) was formed (Scheme 25) [62].

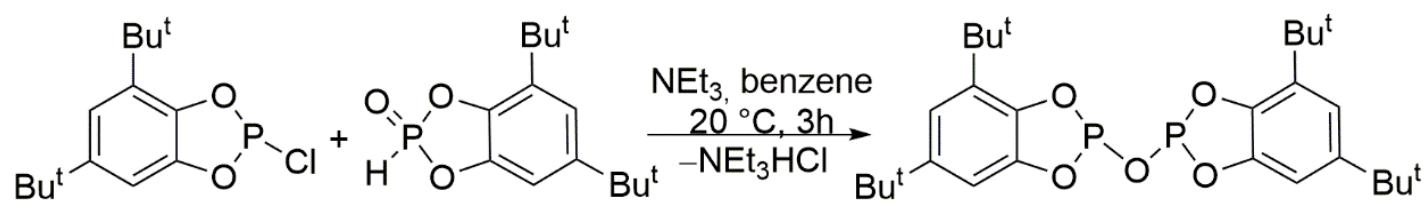

$20 f$ $7 f$

$14 g ; 79 \%$

Scheme 25. The synthesis of $\mathbf{1 4 g}$.

The presence of halogen in the phosphorus electrophile constitution could influence side reactions, such as X-philic substitution [63], disproportionation, or symmetrization processes. Due to these drawbacks, another type of reaction of trivalent phosphorus electrophile, with $1 \mathrm{H}$-imidazole as a leaving group, was studied, in which the $1 \mathrm{H}$-imidazole cyclic phosphate's derivative 1-(5,5-dimethyl-1,3,2-dioxaphosphinan-2-yl)-1H-imidazole (21b) was selected (Scheme 26). The only identified product was a stable anhydride, 2,2'-oxybis(5,5-dimethyl-1,3,2-dioxaphosphinane) (14h) [64]. 


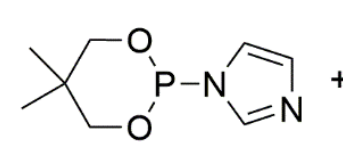

21b

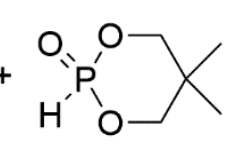

$7 \mathrm{~b}$

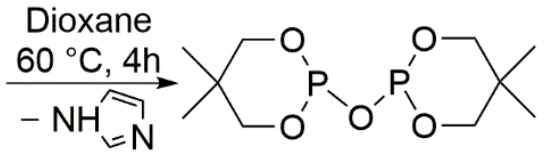

$14 \mathrm{~h} ; 30 \%$

Scheme 26. The synthesis of molecule $\mathbf{1 4 h}$.

\section{P-Centered Radicals Dimerization}

The study of reactions involving organophosphorus radicals has a long history. However, the chemistry of the organophosphorus radical dimerization in terms of mechanism, variation of substitution groups, and reaction conditions is still not sufficiently illustrated $[65,66]$. The phosphinoyl and phosphonyl radicals are non-planar and, as a result, had a variable degree of s-character [66]. From a theoretical point of view, the synthesis of molecules 3 could be realized by the radical dimerization (Scheme 3; Method C). Romakhin et al. investigated the reactivity of phosphorus radicals generated electrochemically in acetonitrile solution (ACN) [67] and found that the dimerization process could produce two different types of compounds 3 and 12 (Scheme 27).

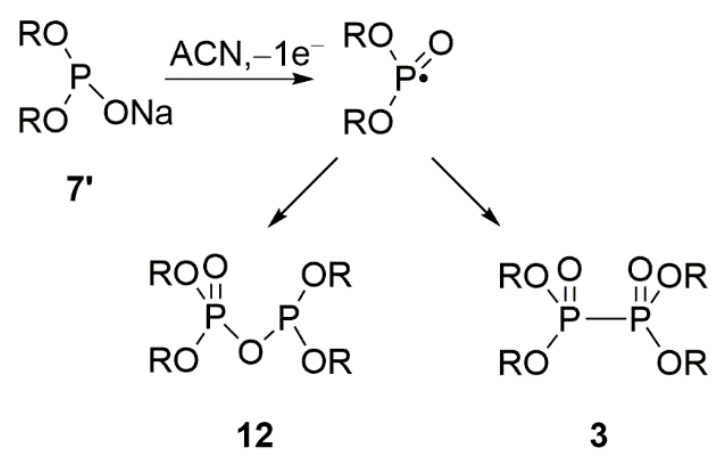

Scheme 27. The dimerization of the phosphorus radicals $>\mathrm{P}(\mathrm{O})^{\bullet}$ in the acetonitrile solution.

The metal (sodium and lithium) salts of dialkyl phosphonates $7^{\prime}$ could be electrochemically oxidized, in which the one-electron oxidation of metal salts $7^{\prime}$ was allowed to generate phosphorus radicals $>\mathrm{P}(\mathrm{O})^{\bullet}$ (Scheme 27). The authors used acetonitrile as a solvent for the electrochemical oxidation processes. It was noticed that the free radicals were generated in the presence of nucleophiles $\mathbf{7}^{\prime}$. A complex product mixture was identified, including anhydrides 10,12, and 14, and molecules 3 in the minority, which have been confirmed by ${ }^{31} \mathrm{P}\left\{{ }^{1} \mathrm{H}\right\}$ NMR. The origin of anhydrides 14 was the result of the reaction between nucleophiles $\mathbf{7}^{\prime}$ and anhydrides $\mathbf{1 2}$ (Scheme 28), which has already been proved by Nycz et al. [68]. The chemical shifts of molecules 3 are given: tetraethyl hypodiphosphate (3a) $\delta=8 \mathrm{ppm}$; tetrapropyl hypodiphosphate (3c) $\delta=10 \mathrm{ppm}$, tetraisopropyl hypodiphosphate (3d) $\delta=6 \mathrm{ppm}$ and tetraisobutyl hypodiphosphate (3e) $\delta=11 \mathrm{ppm}$. The authors found that lithium cation could stimulate the formation of P-P bonds, resulting in higher yields of compound 3.

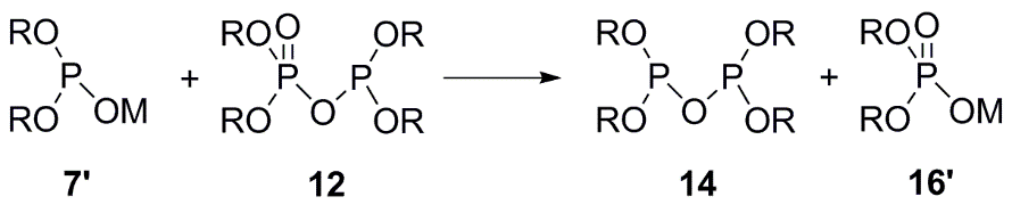

Scheme 28. The reaction between nucleophiles $7^{\prime}$ and anhydrides $\mathbf{1 2}(\mathrm{M}=\mathrm{Na}, \mathrm{Li})$.

Zhou and co-workers showed the first copper-catalyzed P-P bond-forming reactions [69]. They found that the copper-catalyzed P-P bond coupling reaction was highly 
influenced by even slightly changing reaction conditions. The changes could efficiently catalyze an aerobic oxidative dehydrogenative coupling of $H$-phosphonates 7 to selectively produce hypodiphosphoric acid esters 3 or anhydride $\mathbf{1 0}$ (formerly pyrophosphoric acid esters), in high yields (Scheme 29).

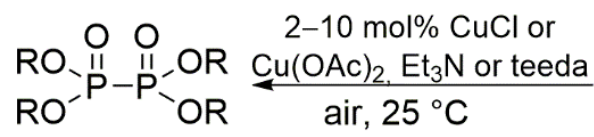

3

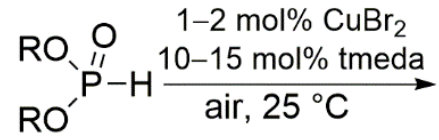

7<smiles>[R]OP([R20])(=O)OP(=O)(O[R])O[R]</smiles>

10

Scheme 29. The copper-catalyzed syntheses of hypodiphosphoric acid esters $\mathbf{3}$ and anhydride $\mathbf{1 0}$ in the presence of an amine.

It was claimed that the synthesis of hypodiphosphoric acid esters 3 led through Pcentered radical dimerization, and efficiently made P-P coupling products: $3 \mathbf{a}(90 \%), \mathbf{3 b}$ $(90 \%),(3 \mathbf{d} ; 93 \%)$, tetrabenzyl hypodiphosphate (3f; $94 \%)$, tetrabutyl hypodiphosphate (3g; $92 \%)$ and tetradodecyl hypodiphosphate (3h; $91 \%)$.

Two years later, Nycz et al. presented work demonstrating the redox reactivity of the metal salts of phosphorus nucleophiles $7^{\prime}$ and $\mathbf{8}^{\prime}$ (where $\mathrm{R}=\mathrm{Ph}, \mathrm{Bu}^{\mathrm{t}}, \mathrm{OCH}_{2} \mathrm{CMe}_{2} \mathrm{CH}_{2} \mathrm{O}$, or $\mathrm{EtO}$ and $\mathrm{M}=\mathrm{Li}$ or $\mathrm{Na}$ ) in the reaction with 7-amino-2-methylquinoline-5,8-dione and $\mathrm{N}$-(2-methyl-5,8-dioxo-5,8-dihydroquinolin-7-yl)acetamide [70]. The nucleophiles $\mathbf{7}^{\prime}$ and $8^{\prime}$ participated in a single-electron transfer (SET) to both quinoline-5,8-dione derivatives, generating the short-lived phosphorus-centered radicals which exclusively and efficiently dimerized to produce molecules: 3a (54\%), 3b (58\%), 1,1,2,2-tetraphenyldiphosphane 1,2-dioxide (4a) (62\%), and meso- and rac- di-1,2-tert-butyl-1,2-diphenyldiphosphine 1,2dioxides $(\mathbf{4} \mathbf{b}, \mathbf{c})(88 \%)$, with high yields (Scheme 30$)$. All charged nucleophiles $\mathbf{7}^{\prime}$ and $\mathbf{8}^{\prime}$ participated in the single-electron transfer to quinoline-5,8-diones, as was postulated by Bunnett [71] and Russell [72]. It is worth mentioning that the in-situ generated P-centered radicals did not undergo radical addition reactions to quinoline-5,8-diones.<smiles></smiles><smiles>[R]Nc1cc(Cl)c2ccc(C)nc2c1O[14C](=O)[O-]</smiles>

Scheme 30. Synthesis of molecules 3 and 4 via P-centered radicals dimerization $(\mathrm{M}=\mathrm{Na}, \mathrm{Li})$.

\section{The Diphosphine Dioxides}

The hypodiphosphoric acid esters 3 and the diphosphine dioxides 4 are related molecules, and they are differentiated by the types of substituents located on phosphorus atoms. The hypodiphosphoric acid esters 3 possess alkoxy and/or aryloxy substituents, and diphosphine dioxides 4 have alkyl and/or aryl (Figure 1). Other molecules like hypodiphosphonates 4 have mixed substituents, i.e., alkyl or aryl and alkoxy or aryloxy or others. The substitution groups disposed of direct impact on the feasibility and efficiency of the reactions. Even nowadays, we lack efficient methods for the synthesis of these compounds. 
The presented data are often incompatible and sometimes contain notable mistakes, e.g., ${ }^{31} \mathrm{P}$ NMR chemical shifts of both meso- and rac- di-1,2-tert-butyl-1,2-diphenyldiphosphine 1,2-dioxides (4b,c) as the same value, namely $48.9 \mathrm{ppm}[70,73]$. However, their chemical shifts are very far from each other $\left(\delta_{\text {rac. }}=50.7\right.$ and $\left.\delta_{\text {meso }}=39.8 \mathrm{ppm}\right)$ [68]. It should be noted here that the syntheses procedures of related diphosphines 23 of the $\mathrm{R}_{2} \mathrm{P}_{-} \mathrm{PR}_{2}$ type ( $\mathrm{R}=\mathrm{Alkyl}$, Aryl) have been described much better, and the results reported in the literature outlined the application, scope, and limitations of the existing protocols [74-76].

The difficulty and even the efficiency of the synthesis were attributed to the equilibrium between molecules $\mathbf{1 5}$ and $\mathbf{1 8}$, where trivalent central phosphorus atom underwent pentavalent. However, the diphosphoxane $\left(\mathrm{CF}_{3}\right)_{2} \mathrm{P}-\mathrm{O}-\mathrm{P}\left(\mathrm{CF}_{3}\right)_{2}$ was only one exception, which was almost completely shifted to the side of the phosphinous acids, with both trivalent phosphorus atoms. The diphosphoxane represented a unique compound showing no rearrangement to a phosphane oxide [13]. The diphosphoxane could be obtained in the reaction between $\left(\mathrm{CF}_{3}\right)_{2} \mathrm{PI}$ with silver carbonate giving the final product an $80 \%$ yield [13].

\subsection{Phosphinito and Phosphito-Mercuries Metal Complexes Decomposition}

From a theoretical perspective, phosphinito and/or phosphito-mercuries metal complexes 9 should be easily decomposed through radical dimerization into the hypodiphosphoric acid esters or the diphosphine dioxides and related molecules (Scheme 3). In 1980

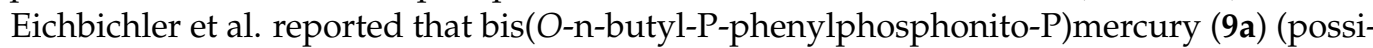
bly a diastereoisomeric mixture of meso and rac) decomposed into the hypodiphosphonic acid ester (4d) (possibly mixture of meso and rac) and metallic mercury at the temperature below $263 \mathrm{~K}$, which was characterized by mass spectroscopy [77]. However, they reported that bis(di-tert-butylphosphinito-P)mercury $(\mathbf{9 b})$ was stable and was not decomposed to the expected 1,1,2,2-tetra-tert-butyldiphosphane 1,2-dioxide (4e) (Scheme 31) [78].<smiles>CCCCOP(=O)([Hg]P(=O)(OCCC)c1ccccc1)c1ccccc1</smiles>

$9 a$<smiles>CC(C)(C)P(=O)([Hg]P(=O)(C(C)(C)C)C(C)(C)C)C(C)(C)C</smiles>

$9 b$<smiles>CCOP(=O)(OCC)c1ccccc1</smiles>

4d

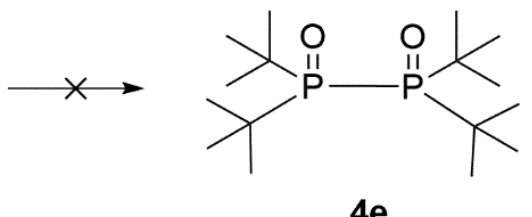

$4 \mathrm{e}$

Scheme 31. Synthesis of molecule $4 \mathrm{~d}$ via metal complex 9a decomposition (no yields were given).

Similarly, in 2008, Nycz reported the preparation of phosphinito and phosphitomercuries [79]. He noticed that during the isolation of final bis(tert-butyl(phenyl)phosphinito) mercury (9c,d), a 1,2-di-tert-butyl-1,2-diphenyldiphosphane 1,2-dioxide (4b,c) (mixture of meso and rac) has been isolated, with $12 \%$ yield (Scheme 32 ). Unfortunately, the origin of molecules $4 \mathbf{b}, \mathbf{c}$ in this experiment is not clear. Systematic studies should be expected where pure metal complexes decompose thermally or under irradiation to produce possible P-centered radicals. 


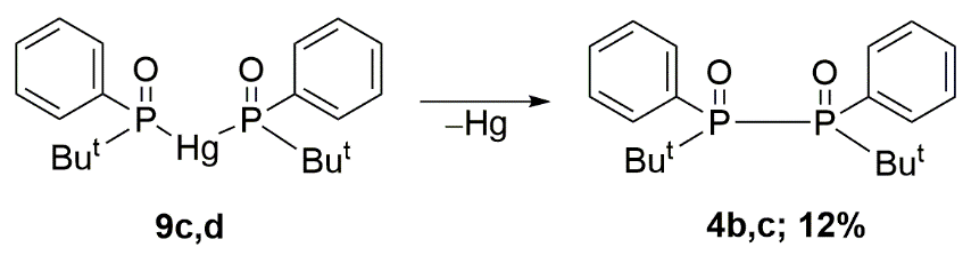

Scheme 32. Synthesis of molecules $4 \mathbf{b}, \mathbf{c}$ via metal complexes $9 c, d$ decomposition.

\subsection{Some Synthetic Approaches of Diphosphine Dioxides}

The diphosphine dioxides 4 can be obtained through the same synthetic routes as previously described in hypodiphosphoric acid esters 3 (Scheme 3). The first method is a reaction between electrophiles 6 , with electron donors such as the alkali metals in heterogeneous ( $\mathrm{Li}$, $\mathrm{Na}, \mathrm{K}$ ) or homogenous conditions (potassium naphthalenide, $\mathrm{Li}, \mathrm{Na}, \mathrm{K}$ in $\mathrm{NH}_{3 \mathrm{liq}}$ ). The first application of the Wurtz-Fittig type synthesis for the P-P bond formation was the coupling of $\mathrm{PI}_{3}$ with mercury to diphosphorus tetraiodide, reported by Besson at the end of the XIX century [80]. Other metals, such as lithium [81], sodium [82-86], potassium [85,86], and magnesium $[87,88]$, in organic solvents have been successfully used for the coupling of the less reactive but more accessible phosphinous halides.

The reaction of compounds $\mathbf{6}$ with alkali metals is complicated, and the data presented in the literature are often inconsistent with each other. Horner et al. isolated, in a poor yield, 1,1,2,2-tetraphenyldiphosphane 1,2-dioxide (4a) from the reaction mixture of diphenylphosphinic chloride (6a) and $\mathrm{Li} / \mathrm{Hg}$ [89]. On the other hand, in the reaction of compound $\mathbf{6 a}$ with sodium in toluene, the formation of sodium diphenylphosphinite $\left(\mathbf{8} \mathbf{b}^{\prime}\right)$ or diphenylphosphido anion (196') was observed, depending on the amount of sodium used in this reaction [90]. Inamoto and co-workers conducted several experiments where electrophile $\mathbf{6 a}$ was treated by alkali metals and metal salts in THF [91]. Sasaki et al. described the reduction of electrophile $6 \mathbf{a}$ with $\mathrm{SmI}_{2}$, at room temperature in THF. They smoothly converted molecule $\mathbf{6 a}$ into the corresponding compound $\mathbf{8 b}$. As a by-product, molecule 4a was isolated with 7\% yield (Scheme 33) [92].

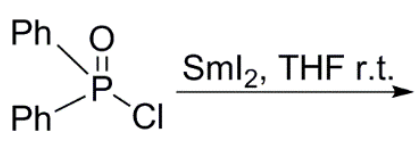

$6 a$<smiles>O=P(c1ccccc1)(c1ccccc1)P(=O)(c1ccccc1)c1ccccc1</smiles>

4a; $7 \%$<smiles>O=[PH]([PH2+])c1ccccc1</smiles>

$8 b ; 75 \%$

Scheme 33. The reduction of molecule 6 a by $\mathrm{SmI}_{2}$.

The presented evidence indicates that the cleavage of $\mathrm{P}-\mathrm{Cl}$ bonds of molecules 6 with electron donors may occur either by one-electron or two-electron pathways. The reductive cleavage of P-C, as well as P-O bonds, may occur. Rachon's team observed the treatment of compounds 6 in THF with one equivalent of potassium metal (with or without the catalysts: naphthalene or 4,4'-ditertbutylbiphenyl) as well as potassium naphthalenide resulted in a complex mixture of products [42,93]. From the theoretical point of view, the electrophile 5 and $\mathbf{6}$ can accept an electron to form an anion radical, which should collapse into a phosphonyl radical and a chlorine anion. The phosphonyl radical, similar to the phosphorus radicals presented in Scheme 27, as a very reactive species, may dimerize to form P-P or P-O-P bond and subsequently accept an electron to form a $>\mathrm{P}^{-} \mathrm{O}^{-}$anion followed by further fragmentation, according to the substituents on the phosphorus and the reaction conditions. At this point, it is worth adding that the reagents of the electrophilic, nucleophilic, and radical characters can exist in such a reaction mixture. Tordo's team also demonstrated that diarylphosphonyl radical can be reduced into diarylphosphinite anion by the electron-rich olefin [65].

The second method of synthesizing compounds 4 is the reaction of electrophiles 6 with appropriate nucleophiles 8 , i.e., diarylphosphine oxides or dialkylphosphine oxides. This 
chemical transformation is similar to the reaction described above for hypodiphosphoric acid esters 3, but with a stronger base, e.g., NaH, alkyllithium, aryllithium, etc. (Scheme 3; method B).

Hunter et al. described the reaction between chlorodiphenylphosphane (20g) and the nucleophile $8 \mathbf{b}$ in the presence and absence of base [94]. The electrophile $20 \mathrm{~g}$ reacted with nucleophile $\mathbf{8 b}$ in the presence of base, giving 1,1,2,2-tetraphenyldiphosphane 1-oxide (18d). Based on the ${ }^{31} \mathrm{P}$ NMR spectroscopy, the authors proved that these reagents reacted to each other in the absence of base, leading to the initial formation of the molecule 18d, which had a characteristic double-doublet with chemical coupling ${ }^{1} J_{\mathrm{PP}}=224 \mathrm{~Hz}$. The compound 18d underwent further transformations with electrophile $20 \mathrm{~g}$ to form tetraphenyldiphosphine (23a) and molecule 6a. The electrophile $\mathbf{6 a}$ could be further deoxygenated by compound $\mathbf{8 b}$ to electrophile $\mathbf{2 0} \mathrm{g}$, and the molecule $\mathbf{8 b}$ was oxygenated to diphenylphosphinic acid (16d). The origin of compounds $16 \mathrm{~d}$ and $23 \mathrm{a}$ was explained to be the side reaction products between 18d and 20g (Scheme 34). These results are consistent with the earlier work of Stec et al.

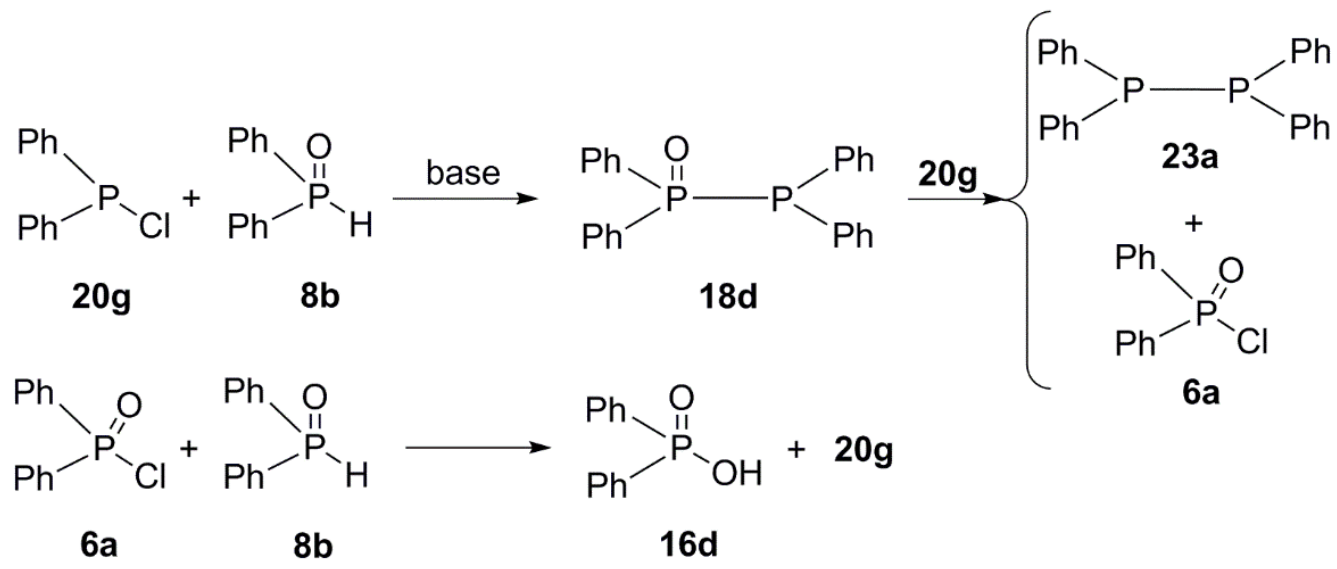

Scheme 34. The possible reaction routes of the reaction between the nucleophile $8 \mathrm{~b}$ and electrophile $20 \mathrm{~g}$.

Majewski et al. reported similar observations that diethylphosphine oxide (8c) reacted with in situ produced diethylphosphinic chloride $(6 \mathbf{b})$ in the reaction of molecule $8 \mathbf{c}$ with $\mathrm{CCl}_{4}$ [95]. Among final products, diethylphosphinic anhydride (11a) was observed, but 1,1,2,2-tetraethyldiphosphane 1,2-dioxide (4f) was not identified. These results are consistent with the earlier work of Steinberg (Scheme 10) [45].

Quin et al. presented the efficient synthesis of symmetrical tetraaryldiphosphine dioxides 4 [96]. The appropriate chlorodiarylphosphanes $\mathbf{2 0}$ in the presence of tertiary amines and exposed to oxygen and water produced the target compounds 4 (Scheme 35). However, when the air was excluded, no compounds 4 were observed. This suggests that the direct reaction product was diphosphine monoxides 18 , which gave target compounds 4 after oxidation. The tetraphenyldiphosphine monoxide (18d) was detected in the reaction mixture. As a result of this chemical transformation, they isolated with high yields 1,1,2,2-tetraphenyldiphosphane 1,2-dioxide (4a; 79\%), 1,1,2,2-tetra-p-tolyldiphosphane 1,2-dioxide (4g; 54\%), 1,1,2,2-tetrabenzyldiphosphane 1,2-dioxide (4h; 56\%), 1,2-bis(4chlorophenyl)-1,2-diphenyldiphosphane 1,2-dioxide (4i; 63\%), 4,4'-(1,2-dioxo-1,2-diphenyl$1 \lambda^{5}, 2 \lambda^{5}$-diphosphane-1,2-diyl)dibenzonitrile $(4 \mathbf{j} ; 56 \%)$. However, the authors did not provide the structural information about compounds $4 \mathbf{i}$ and $4 \mathbf{j}$, which should appear as a mixture of meso and rac diastereoisomers. The reaction of nucleophile $\mathbf{8 b}$ with electrophile $\mathbf{2 0} \mathrm{g}$ in the presence of triethylamine gave a mixture of molecule $\mathbf{4 a}$ (initially formed $\mathbf{1 8 d}$ ) and diphenylphosphinic diphenylphosphinous anhydride (13c) or diphenylphosphinic anhydride (11b) (Scheme 35). 
<smiles>[R]P([R])[Cl+][S-]</smiles>

20

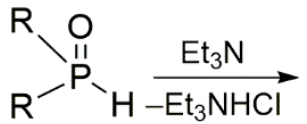

8<smiles>[R]P([R])[P+]([R])([R])[O-]</smiles>

18<smiles>[R][R]([R])([R])P([R])([R])=O</smiles>

4

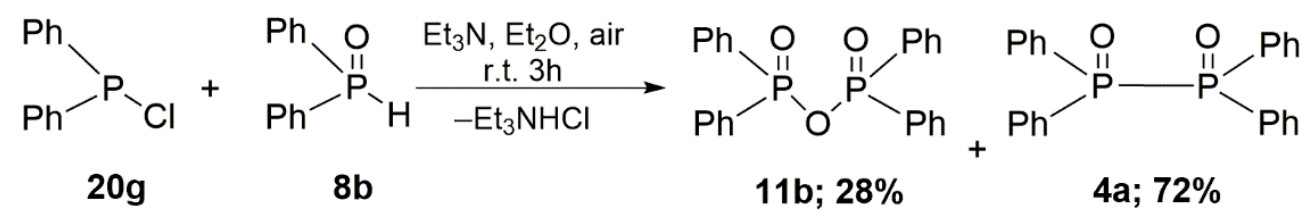<smiles>O=P(OP(c1ccccc1)c1ccccc1)(c1ccccc1)c1ccccc1</smiles>

$13 c$

Scheme 35. Synthesis of molecules 4. The possible reaction routes of the reaction between the nucleophile $\mathbf{8 b}$ and electrophile $\mathbf{2 0 g}$ (no yield of $\mathbf{1 3 c}$ was given).

Quin et al. were the first to recognize the duality in secondary phosphine oxides $8^{\prime}$ s chemical character because only the existence of $O$-phosphorylation could explain the obtained anhydrides $\mathbf{1 1} \mathbf{b}$ and $\mathbf{1 3 c}$ [95]. Ambident phosphorus nucleophiles $\mathbf{8}^{\prime}$ of the type $>\mathrm{P}_{-}-\mathrm{O}^{-}$could react through either the $P$ or $O$ nucleophilic centre with phosphorus electrophiles $\mathbf{6}$ or 20 to produce both $P$-phosphorylated products 4 or $O$-phosphorylated compounds $\mathbf{1 1}$ mixed with anhydrides $\mathbf{1 3}$. The pattern of the yield distribution depends on the substituent located on the phosphorus atom, which was controlled by steric and/or electronic factors.

Many results reported above showed mysterious "oxidized" and "reduced" anhydrides 11 and 13, respectively, as the products of the syntheses of molecules 4 . To explain this puzzle, Rachon's team performed the reaction of mixed anhydrides $\mathbf{1 3}$ with the metal salts of nucleophile $\mathbf{8}^{\prime}$, having the phosphorus atom surrounded by identical substituents. They performed reactions between the mixed anhydrides 13a,b, and 5,5-dimethyl-1,3,2dioxaphosphinan-2-yl tert-butyl(phenyl)phosphinate (13d) and the potassium salts of nucleophiles $\mathbf{7} \mathbf{b}^{\prime}$ and $\mathbf{8} \mathbf{b}^{\prime}$, which possessed the identical substituents located on the trivalent phosphorus atom in the constitution of mixed anhydrides $\mathbf{1 3}$ (Scheme 36) [68]. It is important to mention that Stec et al. found that the mixed anhydride $\mathbf{1 2} \mathbf{b}$ did not react with either nucleophile $\mathbf{7 a}$ in the presence of triethylamine at room temperature or electrophile 5a. The metal salts of nucleophiles 7 and 8 are stronger reagents than those generated in the reaction between molecules 7 and 8 and triethylamine.

The reactions between the metal salts of nucleophiles 7 and 8 with mixed anhydrides 13 were very selective. The trivalent phosphorus atoms were always attacked by nucleophiles $7 \mathbf{b}^{\prime}$ or $8 \mathbf{c}^{\prime}$, giving $P$ - or $O$-phosphorylated products $18 \mathrm{e}, \mathbf{f}$, and $14 \mathrm{~h}$, respectively, and an acid anion $\mathbf{1 6} \mathbf{c}^{\prime}$ as a leaving group (Scheme 36). Depending on the nature of substituents, the diphosphine monoxides $18 \mathrm{e}, \mathrm{f}$, or the anhydride $14 \mathrm{~h}$ were obtained. Hydrolysis, oxygenation, or sulfuration gave the final products in similar molar yields in both cases. The trivalent phosphorus atom of diphosphine monoxides 18e, $\mathbf{f}$ were oxidized or sulfurated to produced molecules $4 \mathbf{b}, \mathbf{c}$ or $4 \mathbf{k}, \mathbf{l}$ with good yields. In the next step, acid anions $16 \mathbf{c}^{\prime}$ can be reacted easily with phosphorus electrophiles 6 to produce phosphorus acid anhydrides $\mathbf{1 1}$ as "oxidized" products. These results are compatible and consistent with the earlier work of Zwierzak et al. (Schemes 4-6) [40]. 

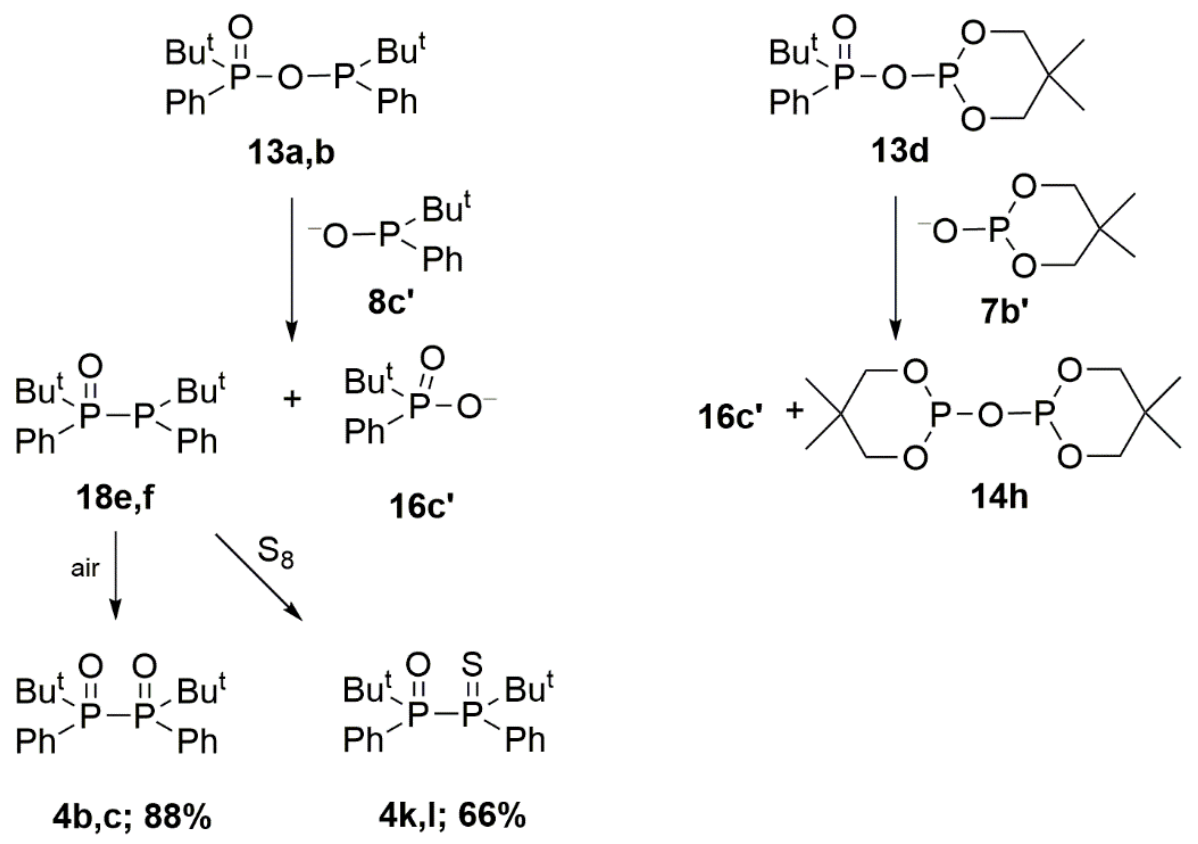

Scheme 36. The reaction between the nucleophiles $7 \mathbf{b}^{\prime}$ and $8 \mathbf{c}^{\prime}$ with mixed anhydrides $\mathbf{1 3 d}$ and $\mathbf{1 3 a}, \mathbf{b}$, respectively.

In the aforementioned reaction between nucleophile $\mathbf{8}^{\prime}$ and electrophiles 6 , two nucleophiles coexisted in the reaction mixture: $\mathbf{8}^{\prime}$ and $\mathbf{1 6}^{\prime}$. The $>\mathrm{P}-\mathrm{O}^{-}$anion, nucleophile $\mathbf{8}^{\prime}$ as an $\alpha$-nucleophile should react faster with electrophiles 6 than the acid anion $16^{\prime}$. Thus, the increase of nucleophile $\mathbf{6}^{\prime}$ concentration should increase the amount of molecule 4 . These results are in line with the earlier work of Michalski et al. (25\% excess of nucleophilic reagent $\mathbf{7} \mathbf{a}^{\prime}$ ) [39] and (50\% excess sodium salts of diethyl phosphonate $\mathbf{7} \mathbf{a}^{\prime}$ ) [49]. According to Pearson's hard and soft acid and base principle, leaving the group could affect the ratio of $P$ - vs. O-phosphorylated product [97]. Thus, nucleophilic substitution proceeds faster when the nucleophile and the leaving group are either hard or soft. Consequently, obtaining higher yields of compounds 4 requires modifying the softness of the phosphorus atom substituents. This can be achieved by changing the halogen atom bound to the phosphorus in electrophiles 6, from $\mathrm{Cl}$ through $\mathrm{Br}$ to I. A reaction of nucleophiles 7 or 8 with iodine seems to be an exciting idea, which guarantees a temporary excess of the nucleophile. Moreover, iodine, as opposite to bromine, did not quantitatively react with compounds 3 . Quite surprisingly, the reaction of nucleophiles $7^{\prime}$ or $\mathbf{8}^{\prime}$ and iodine in THT or THF $/ \mathrm{NH}_{3 l i q}$. yielded compounds 3 and 4 efficiently, which obtained diphosphine dioxides 4 in $98 \%$ and hypophosphoric acid esters 3 in $48 \%$ yields in a facile and convenient way. The reaction of iodine and nucleophiles $\mathbf{7}^{\prime}$ or $\mathbf{8}^{\prime}$ anion generated in situ proceeded efficiently in both THF and liquid ammonia. Moreover, it appeared that the dissolution rate of solid iodine limited the reactivity of iodine in liquid ammonia at $-78{ }^{\circ} \mathrm{C}$. In the reaction mixture tertbutyl(phenyl)phosphinic iodide $\mathbf{6 b}$ was isolated with $1 \%$ yield. The results, especially from liquid ammonia, suggest that the reaction proceeded via radical mechanism rather than pure nucleophilic substitution. The alkoxy group as a phosphorus substituent reduced the efficiency of compounds 3 because the iodide anion could react with alkoxy substituents (see Arbuzov's reaction).

The synthesis of unsymmetrical compounds 3 or 4 , in which one fragment would come from nucleophilic molecule $\mathbf{7}$ or $\mathbf{8}$ and the second from electrophilic 5 or $\mathbf{6}$, was much more complicated. Both reagents can undergo X-philic substitution [63], which leads to the exchange of characters of reagents, and in effect, symmetrical and unsymmetrical compounds 4 (Scheme 37). 


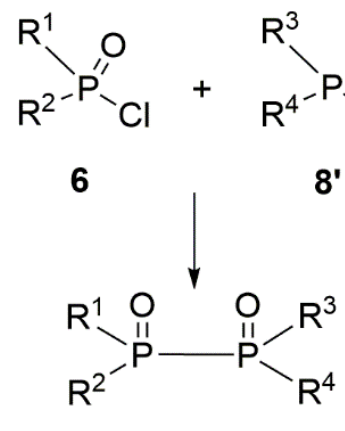

4

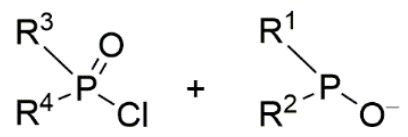

6

8'

Scheme 37. The synthesis of unsymmetrical compounds 4 . The X-philic substitution reaction between the nucleophile 8 and electrophile 6 .

In 1983, Foss et al. carried out a thermal inducted rearrangement of unsymmetrical molecule 18g [98] and determined the equilibrium between compounds 18 and 15. Some interesting rearrangement and symmetrization similar to the above-described reactivity were observed (Scheme 38). It was suggested that monoxides 18 preferred the alkyl substituents, but anhydrides 15 alkoxyl.

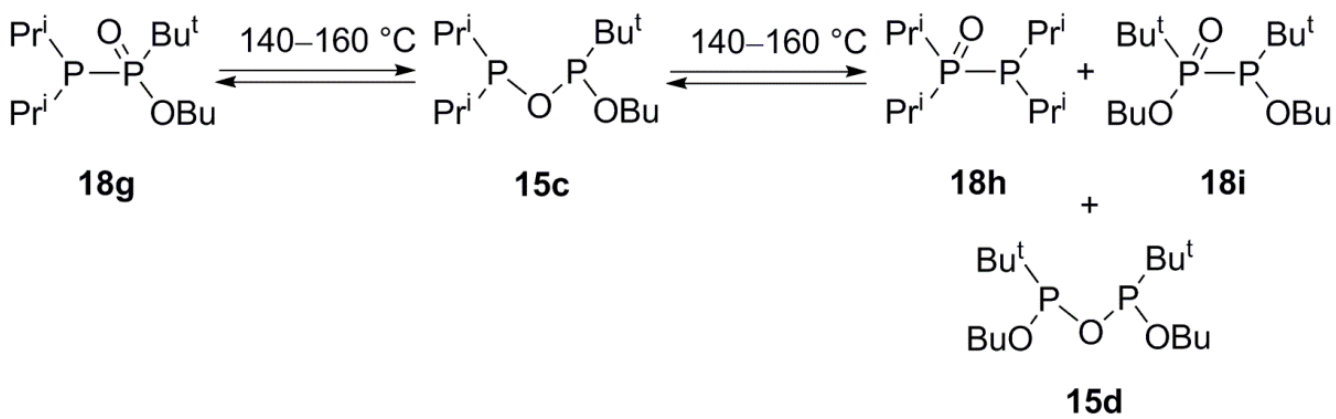

Scheme 38. The thermal inducted rearrangement of diphosphine monoxide 18g.

\section{The Analogs of Biologically Active Compounds That Possess a P-P bond}

The synthesis of molecules 3 depended on the type of substituents on the phosphorus atom, as is shown above. Elaborate procedures helped to obtain these interesting molecules. However, the syntheses of analogs of biologically active compounds that possess a P-P bond are still challenging.

Zhou et al. synthesized molecule 3i derivatives of 1-(5-(hydroxymethyl)-2,5-dihydrofur an-2-yl)-5-methylpyrimidine-2,4(1H,3H)-dione in high yield by using copper as catalyst (Scheme 39) [69].<smiles>CCOP(=O)(O)OC[C@@H]1C=C[C@@H](n2cc(C)c(=O)[nH]c2=O)O1</smiles>

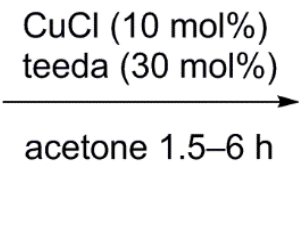<smiles></smiles>

$3 i ; 78 \%$

Scheme 39. The synthesis of molecule $3 \mathbf{i}$, an analog of 5-methylpyrimidine-2,4(1H,3H)-dione in the presence of $N, N, N^{\prime}, N^{\prime}$-tetraethylethylenediamine (teeda).

The antitumor activity of hypodiphosphoric acid 3 is potentially crucial in cancer treatment because the synthesis of deoxythymidine monophosphate (dTMP) is critical 
during rapid cell proliferation [99]. In general, most normal mammalian cells grow slowly and require less dTMP, hence the interruption of its synthesis can selectively kill cancer cells.

Dirheimer succeeded to obtained hypodiphosphorylated derivatives of nucleotides from hypodiphosphoric acid salts (1). The limited characterization data about the structure of hypodiphosphoric acid (1) hindered the clarity of the results, mainly because of the unavailability of ${ }^{31} \mathrm{P}$ NMR data $[100,101]$.

Recently, Sepulveda-Boza published a synthetic procedure about the modified nucleotide of cytidine containing three directly connected phosphorus atoms, i.e., the PAPB-PC system [8]. The absence of coupling constants between phosphorus atoms in the presented data left room for further clarification about these results. Coupling constants should be distinguished between each connected phosphorus atom.

Setondji et al. obtained adenosine $5^{\prime}$-O-hypodiphosphate (3j) by DCC-assisted condensation of hypodiphosphoric acid (1) with (( $3 \mathrm{a} R, 4 R, 6 R, 6 \mathrm{a} R)-6$-(6-amino-9H-purin-9-yl)2,2-dimethyltetrahydrofuro [3,4-d][1,3]dioxol-4-yl)methanol (Scheme 40) [101].

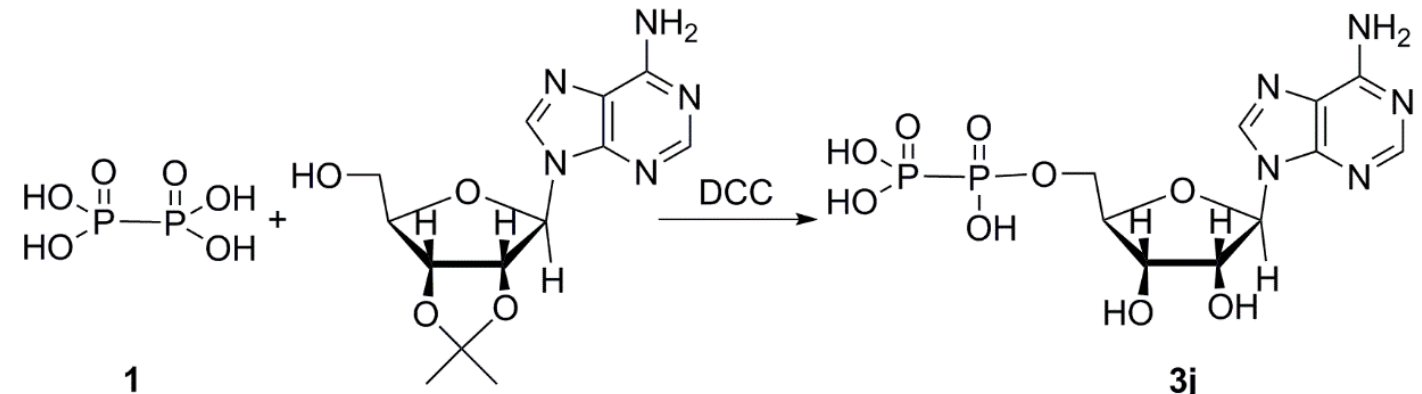

Scheme 40. The synthesis of adenosine 5'-O-hypodiphosphate (3j) in the presence of dicyclohexylcarbodiimide (DCC).

Recently, Stec and co-workers presented a brilliant method for forming organohypodiphosphates containing a P-P bond under mild conditions [1]. They obtained hypodiphosphoric acid esters $3 \mathbf{k}, 3 \mathbf{3}$, and $3 \mathrm{~m}$ by applying the DBU as a base in the reaction of 2alkoxy-2-thio-1,3,2-oxathiaphospholanes with nucleophiles 7, O,O-dialkyl $\mathrm{H}$-phosphonates or $H$-thiophosphonates (Scheme 41).<smiles>[R6][PH]1(=S)[CH-][CH+]CO1</smiles><smiles>[R20][PH]([R20])=O</smiles>

7

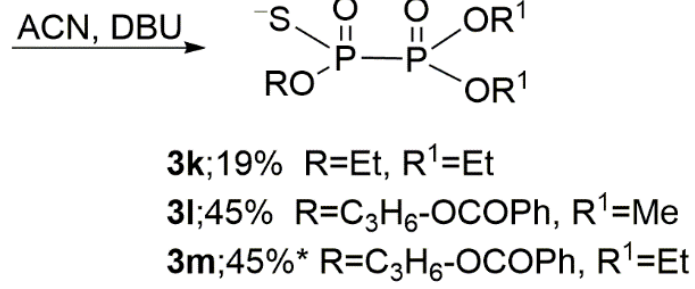

$\stackrel{\mathrm{ACN}, \mathrm{DBU}}{\longrightarrow}$

$\mathbf{3 k} ; 19 \% \quad \mathrm{R}=\mathrm{Et}, \mathrm{R}^{1}=\mathrm{Et}$

$3 \mathrm{l} ; 45 \% \mathrm{R}=\mathrm{C}_{3} \mathrm{H}_{6}-\mathrm{OCOPh}, \mathrm{R}^{1}=\mathrm{Me}$

$3 m ; 45 \% * R=\mathrm{C}_{3} \mathrm{H}_{6}-\mathrm{OCOPh}, \mathrm{R}^{1}=\mathrm{Et}$

Scheme 41. The synthesis of hypodiphosphoric acid esters $3 \mathbf{k}, 31$ and $3 \mathbf{m}$ ( ${ }^{*}$ not isolated) in the presence of acetonitrile (ACN) and 1,4-diazabicyclo[5 .4.0]undec-7-ene (DBU).

The structures of molecules $3 \mathbf{k}, 3 \mathbf{l}$, and $3 \mathrm{~m}$ have been characterized by ${ }^{31} \mathrm{P} \mathrm{NMR}$, ${ }^{1} \mathrm{H}-\mathrm{NMR}$, and FAB MS techniques. ${ }^{31} \mathrm{P}-\mathrm{NMR}$ spectra confirmed the presence of a P-P bond in the constitution of 3 . On ${ }^{31} \mathrm{P}-\mathrm{NMR}$ spectrum of $\mathbf{3 k}$, due to inequivalent phosphorus atoms, two pairs of doublets with spin-spin coupling constants ${ }^{1} J_{\mathrm{PP}}=466 \mathrm{~Hz}$ are present. In other experiments, cyclic derivatives of uridine (Ura) $3 n$ and adenosine (Ade) $3 \mathbf{o}$ were synthesized (Scheme 42). 
<smiles>[X]OC1C([Al])OC(COP2(=S)OCCS2)C1O[X]</smiles><smiles></smiles>

$7 a$<smiles>COP(=O)(OC)P(=O)([S-])OCC1OC([Al])C(O)C1O</smiles>

3n (Ura) $38 \%$

30 (Ade) $24 \%$

Scheme 42. The synthesis of uridine (Ura) and adenosine (Ade) hypodiphosphate derivatives $\mathbf{3 n}$ and 30 in the presence of DBU.

The authors reported the oxathiaphospholane method of $\mathrm{P}-\mathrm{P}$ bond formation in another example of the synthesis of nucleoside hypodiphosphate derivative $3 p$ (Scheme 43).

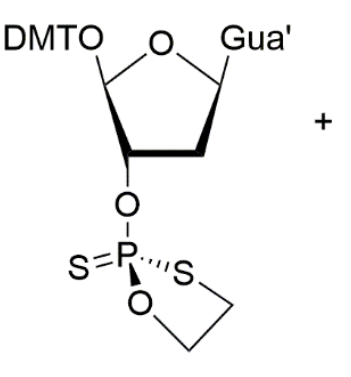<smiles>CCOP(=O)(OCC)OCC</smiles>

$7 a$<smiles>CCOP(=O)(OCC)P(=O)(S)OC1CC2OC1C2OC</smiles>

$3 p$

Scheme 43. The synthesis of nucleoside hypodiphosphate derivative $3 p$ in the presence of DBU (no yield was given).

The authors also carried out interesting preliminary studies on the biological activity of the compounds they obtained [1]. Guranowski et al. investigated how the biological activity of adenosine $5^{\prime}$-hypodiphosphate $3 \mathbf{j}$ modified the molecule to carry a P-P bond (Scheme 40) [2]. None of the HIT-proteins cleaved its P-P bond and liberated pA. They concluded that natural proteins do not recognize compounds $3 \mathbf{j}$ with $\mathrm{P}-\mathrm{P}$ bond because of their non-existing in living systems. Moreover, they added that, in addition to their previous unpublished observations, molecule $3 \mathbf{j}$ was also refractory to other hydrolases (bacterial alkaline phosphatase, lupin apyrase, and snake venom phosphodiesterase) and that compound $\mathbf{3 j}$ did not inhibit these enzymes. Only snake venom 50-nucleotidase slowly hydrolyzed this compound and released adenosine.

\section{Conclusions}

In this review, the syntheses of the molecules 3 and 4 containing $>\mathrm{P}(=\mathrm{O})-\mathrm{P}(=\mathrm{O})<$ fragment are described. Despite the lack of a well-developed mechanism, the well-known Salzer's synthetic procedure of hypodiphosphoric acid (1) is constantly used. The acid $\mathbf{1}$ is unstable under acidic conditions and disproportionate to $\mathrm{H}_{3} \mathrm{PO}_{4}$ and $\mathrm{H}_{3} \mathrm{PO}_{3}$. The $\mathrm{P}-\mathrm{P}$ distance is close to $2.182 \AA$, and the $\mathrm{P}-\mathrm{O}$ bond lengths range from 1.501 to $1.569 \AA$. The ${ }^{31} \mathrm{P}\left\{{ }^{1} \mathrm{H}\right\}$ CPMAS NMR measurements showed that the hypodiphosphates $\mathbf{1}^{\prime}$ exhibit a single resonance in the range from $14.9 \mathrm{ppm}$ to $11.4 \mathrm{ppm}$. The acid $\mathbf{1}$ and its salts show ferroelectricity properties.

The structure of related molecules, the hypodiphosphoric acid esters 3 , and the diphosphine dioxides 4 are stabilized by alkyl, aryl, and cyclic substituents which are directly connected to the phosphorus atom. The use of an excess of nucleophiles during the synthesis of molecules 3 and 4 is also beneficial. The lithium cation could better stimulate the formation of P-P bonds than other alkali metals, resulting in higher yields of compounds 3 and 4 , which requires modifying the softness of the phosphorus atom substituents. This 
can be achieved by changing the substituents, including the halogen atom bound to the phosphorus in the constitution of electrophiles $\mathbf{5}$ and $\mathbf{6}$, from $\mathrm{Cl}$ through $\mathrm{Br}$ to I.

The oxathiaphospholane method of P-P bond formation during the synthesis of biologically active analogs is an interesting idea that allows the syntheses of further compounds with potential biological activities. However, some authors have concluded that natural proteins did not recognize compounds with P-P bonds because of their non-existing living systems.

The P-centered phosphorus radicals could dimerize to produce compounds 3 and 4 , which are considered precursors of $>\mathrm{P}(=\mathrm{O})^{\bullet}$ type radicals. The studies of reactions involving organophosphorus radicals have great potential in organophosphorus and medicinal chemistry.

Funding: This research received no external funding.

Conflicts of Interest: The author declare no conflict of interest.

$\begin{array}{ll}\text { Abbreviations } \\ \text { ACN } & \text { Acetonitrile } \\ \text { DBU } & \text { 1,4-diazabicyclo[5 .4.0] undec-7-ene } \\ \text { THF } & \text { Tetrahydrofuran } \\ \text { TFA } & \text { Trifluoroacetic acid } \\ \text { DCC } & \text { Dicyclohexylcarbodiimide } \\ \text { TEEDA } & N, N, N^{\prime}, N^{\prime} \text {-tetraethylethylenediamine } \\ \text { dTMP } & \text { Deoxythymidine monophosphate } \\ \text { CP MAS } & \text { Cross polarization magic angle spinning } \\ \text { CP-HETCOR } & \text { Cross polarization-Heteronuclear correlation } \\ \text { FAB MS } & \text { Fast atom bombardment mass spectrometry } \\ \text { HOMO } & \text { High occupied molecular orbital } \\ \text { HIT-protein } & \text { The histidine triad protein }\end{array}$

\section{References}

1. Błaziak, D.; Guga, P.; Jagiełło, A.; Korczyński, D.; Maciaszek, A.; Nowicka, A.; Pietkiewicz, A.; Stec, W. Stereoselective formation of a P-P bond in the reaction of 2-alkoxy-2-thio-1,3,2-oxathiaphospholanes with $O, O$-dialkyl $H$-phosphonates and H-thiophosphonates. J. Org. Biomol. Chem. 2010, 8, 5505-5510. [CrossRef]

2. Guranowski, A.; Wojdy, A.M.; Zimny, J.; Wypijewska, A.; Kowalska, J.; Łukaszewicz, M.; Jemielity, J.; Darżynkiewicz, E.; Jagiełło, A.; Bieganowski, P. Recognition of different nucleotidyl-derivatives as substrates of reactions catalyzed by various HIT-proteins. New J. Chem. 2010, 34, 888-893. [CrossRef]

3. Salzer, T. Ueber die Unterphosphorsäure. Liebigs Ann. 1877, 187, 322-341. (In German) [CrossRef]

4. Salzer, T. Ueber Unterphosphorsäure und deren Salze. Liebigs Ann. 1878, 194, 28-39. (In German) [CrossRef]

5. Salzer, T. Ueber Unterphosphorsäure. Liebigs Ann. 1882, 211, 1-35. (In German) [CrossRef]

6. Salzer, T. Ueber Unterphosphorsäure. Vierte Abhandlung. Liebigs Ann. 1886, 232, 114-121. (In German) [CrossRef]

7. Leininger, E.; Chulski, T. Disodium dihydrogen hypophosphate. Inorg. Synth. 1953, 4, 68-71.

8. Prokop, M.; Bystron, T.; Paidar, M.; Bouzek, $\mathrm{K} . \mathrm{H}_{3} \mathrm{PO}_{3}$ electrochemical behavior on a bulk Pt electrode: Adsorption and oxidation kinetics. Electrochim. Acta 2016, 212, 465-472. [CrossRef]

9. Greenwood, N.N.; Earnshaw, A. Chemistry of the Elements, 2nd ed.; Butterworth-Heinemann: Oxford, UK, 1997; pp. 473-546.

10. Greenwood, N.N.; Earnshaw, A. Chemistry of the Elements; Pergamon Press: Oxford, UK, 1984; p. 590.

11. Hoge, B.; Garcia, P.; Willner, H.; Oberhammer, H. Bis(trifluoromethyl)phosphinous Acid $\left(\mathrm{CF}_{3}\right)_{2} \mathrm{P}-\mathrm{O}-\mathrm{H}$ : An Example of a Thermally Stable Phosphinous Acid-Synthesis, Gas-Phase Structure, and Rotational Isomers. Chem. Eur. J. 2006, 12, 3567-3574. [CrossRef] [PubMed]

12. Griffiths, J.E.; Burg, A.B. The phosphinous acid $\left(\mathrm{CF}_{3}\right)_{2} \mathrm{POH}$ and the diphosphoxane $\left(\mathrm{CF}_{3}\right)_{2} \mathrm{POP}\left(\mathrm{CF}_{3}\right)_{2}$. J. Am. Chem. Soc. 1960, 82, 1507-1508. [CrossRef]

13. Hoge, B.; Neufeind, S.; Hettel, S.; Wiebe, W.; Thösen, C. Stable phosphinous acids. J. Organomet. Chem. 2005, 690, $2382-2387$. [CrossRef]

14. Mootz, D.; Altenburg, H. Kristallstrukturen von Säurehydraten und Oxoniumsalzen. VI. Dioxonium-dihydrogen-hypophosphat, $\left(\mathrm{H}_{3} \mathrm{O}^{+}\right)_{2}\left[\mathrm{H}_{2} \mathrm{P}_{2} \mathrm{O}_{6}{ }^{2-}\right]$. Acta Crystallogr. B 1971, 27, 1520-1523. (In German) [CrossRef]

15. Collin, R.L.; Willis, $\mathrm{M}$. The crystal structure of disodium dihydrogen hypophosphate hexahydrate $\left(\mathrm{Na}_{2} \mathrm{H}_{2} \mathrm{P}_{2} \mathrm{O}_{6} \cdot 6 \mathrm{H}_{2} \mathrm{O}\right)$ and disodium dihydrogen pyrophosphate hexahydrate $\left(\mathrm{Na}_{2} \mathrm{H}_{2} \mathrm{P}_{2} \mathrm{O}_{7} \cdot 6 \mathrm{H}_{2} \mathrm{O}\right)$. Acta Crystallogr. B 1971, 27, 291-302. [CrossRef] 
16. Szafranowska, B.; Ślepokura, K.; Lis, T. Structural analysis of six potassium salts of hypodiphosphoric acid, $\mathrm{H}_{4} \mathrm{P}_{2} \mathrm{O}_{6}$, containing the anions in all possible basicities, is focused on the anion structure and the organization of the anionic and cationic sublattices. Acta Crystallogr. C 2012, 68, i71-i82. [CrossRef] [PubMed]

17. Gjikaj, M.; Wu, P.; Brockner, W. New Quaternary Alkali-Metal Hypodiphosphate Hydrates: Preparation, Crystal Structure, Vibrational Spectrum, and Thermal Behavior of $\mathrm{K}_{4} \mathrm{P}_{2} \mathrm{O}_{6} \cdot 8 \mathrm{H}_{2} \mathrm{O}$ and $\mathrm{Na}_{2} \mathrm{~K}_{2} \mathrm{P}_{2} \mathrm{O}_{6} \cdot 8 \mathrm{H}_{2} \mathrm{O}$ in Comparison to $\mathrm{Na}_{4} \mathrm{P}_{2} \mathrm{O}_{6} \cdot 10 \mathrm{H}_{2} \mathrm{O} . \mathrm{Z}$. Anorg. Allg. Chem. 2012, 638, 2144-2149. [CrossRef]

18. Wu, P.; Wiegand, T.; Eckert, H.; Gjikaj, M. New hypodiphosphates of the alkali metals: Synthesis, crystal structure and vibrational spectra of the hypodiphosphates(IV) $\mathrm{M}_{2}\left[\left(\mathrm{H}_{2} \mathrm{P}_{2} \mathrm{O}_{6}\right)\left(\mathrm{H}_{4} \mathrm{P}_{2} \mathrm{O}_{6}\right)\right](\mathrm{M}=\mathrm{Rb}$ and Cs). J. Solid State Chem. 2012, 194, 212-218. [CrossRef]

19. Gjikaj, M.; Wu, P.; Brockner, W. Preparation, Crystal Structure, Vibrational Spectra, and Thermal Behavior of $\mathrm{Rb}_{2} \mathrm{H}_{2} \mathrm{P}_{2} \mathrm{O}_{6} \cdot 2 \mathrm{H}_{2} \mathrm{O}$. Z. Anorg. Allg. Chem. 2014, 640, 379-384. [CrossRef]

20. Gjikaj, M.; Haase, M. Crystal structure of catena-poly[[tetraaquamagnesium]- $\mu$-(dihydrogen hypodiphosphato)- $\left.\kappa^{2} O: O^{\prime}\right]$. Acta Crystallogr. E 2015, 71, 867-869. [CrossRef] [PubMed]

21. Haase, M.; Gjikaj, M. Preparation, Crystal Structure and Vibrational Spectra of $\mathrm{Ca}_{2} \mathrm{P}_{2} \mathrm{O}_{6} \cdot 2 \mathrm{H}_{2} \mathrm{O}$ and $\left[\mathrm{Ca}\left(\mathrm{H}_{2} \mathrm{O}\right)_{3}\left(\mathrm{H}_{2} \mathrm{P}_{2} \mathrm{O}_{6}\right)\right] \cdot 0.5\left(\mathrm{C}_{12}\right.$ $\left.\mathrm{H}_{24} \mathrm{O}_{6}\right) \cdot \mathrm{H}_{2} \mathrm{O}$. Z. Anorg. Allg. Chem. 2017, 643, 962-967. [CrossRef]

22. Palkina, K.K.; Maksimova, S.I.; Chibiskova, N.T.; Mironova, K.S.; Tananaev, I.K. Crystal structure of $\mathrm{LnHP}_{2} \mathrm{O}_{5} \cdot 4 \mathrm{H}_{2} \mathrm{O}\left(\mathrm{Ln}_{-} \mathrm{Gd}\right.$, Dy, $\mathrm{Ho}$ ) and change of P-P bond length in hypophosphate anion at $\mathrm{Ln}=\mathrm{Nd}-\mathrm{Yb}$. Russ. J. Inorg. Chem. 1987, 32, $1790-1792$.

23. Hagen, S.; Jansen, M. Darstellung und Kristallstruktur von Cobalt(II)-Hexaoxodiphosphat $(\mathrm{P}-\mathrm{P})(4-)$-dodecahydrat, $\mathrm{Co}_{2} \mathrm{P}_{2} \mathrm{O}_{6} \cdot 12$ $\mathrm{H}_{2}$ O. Z. Anorg. Allg. Chem. 1995, 621, 149-152. [CrossRef]

24. Haag, J.M.; LeBret, G.C.; Cleary, D.A.; Twamley, B. Room temperature synthesis and solid-state structure of $\mathrm{Ni}_{2} \mathrm{P}_{2} \mathrm{O}_{6} 12 \mathrm{H}_{2} \mathrm{O}$. J. Solid State Chem. 2005, 178, 1308-1311. [CrossRef]

25. Gjikaj, M.; Wu, P.; Pook, N.-P. Hexaaquanickel(II) dihydrogen hypodiphosphate. Acta Crystallogr. E 2013, 69, i83. [CrossRef] [PubMed]

26. Wu, P.; Pook, N.P.; Gjikaj, M. Darstellung und Kristallstruktur von Cobalt((II)-Hexaoxodiphosphat(P-P)(4-)-dodecahydrat, $\mathrm{Co}_{2}, \mathrm{P}_{2} \mathrm{O}_{6} 12 \mathrm{H}_{2} \mathrm{O}$. Z. Anorg. Allg. Chem. 2015, 641, 1755-1761. [CrossRef]

27. Gjikaj, M.; Wu, P. Transition Metal Complexes Containing Dihydrogen Hypodiphosphate in Eclipsed Conformation as Ligand: Preparation, Crystal Structure, Vibrational Spectra, and Thermal Behavior of $\mathrm{K}_{2}\left[\mathrm{M}_{(}\left(\mathrm{H}_{2} \mathrm{P}_{2} \mathrm{O}_{6}\right)_{2}\left(\mathrm{H}_{2} \mathrm{O}\right)_{2}\right] \cdot \mathrm{H}_{2} \mathrm{O}(\mathrm{M}=\mathrm{Co}, \mathrm{Ni}$, Cu, and Zn). Z. Anorg. Allg. Chem. 2014, 640, 189-194. [CrossRef]

28. Kinzhybalo, V.; Mermer, A.; Lis, T.; Starynowicz, P. Electron density distribution in tetralithium hypodiphosphate hexahydrate, $\mathrm{Li}_{4} \mathrm{P}_{2} \mathrm{O}_{6} \cdot 6 \mathrm{H}_{2} \mathrm{O}$. Acta Crystallogr. B 2013, 69, 344-355. [CrossRef] [PubMed]

29. Otręba, M.; Budzikur, D.; Górecki, Ł.; Ślepokura, K.A. Adenosine hypodiphosphate ester, an analogue of ADP: Analysis of the adenine-hypodiphosphate interaction mode in hypodiphosphate nucleotides and adenine salts. Acta Crystallogr. C 2018, 74, 571-583. [CrossRef] [PubMed]

30. Emami, M.; Ślepokura, K.A.; Trzebiatowska, M.; Noshiranzadeh, N.; Kinzhybalo, V. Oxyanion clusters with antielectrostatic hydrogen bonding (AEHB) in tetraalkylammonium hypodiphosphates. CrystEngComm 2018, 20, 5209-5219. [CrossRef]

31. Wilson, A.; McGeachin, M.M. The Crystal Structure of Diammonium Dihydrogen Hypophosphate $\left(\mathrm{NH}_{4}\right)_{2} \mathrm{H}_{2} \mathrm{P}_{2} \mathrm{O}_{6} \cdot A_{c t a}$ Crystallogr. 1964, 17, 1352-1355. [CrossRef]

32. Ourvard, G.; Brec, R.; Rouxel, J. Structural determination of some $\mathrm{MPS}_{3}$ layered phases (M= Mn, Fe, Co, Ni and Cd). Mater. Res. Bull. 1985, 20, 1181-1189.

33. Szklarz, P.; Chański, M.; Ślepokura, K.; Lis, T. Discovery of Ferroelectric Properties in Diammonium Hypodiphosphate $\left(\mathrm{NH}_{4}\right)_{2} \mathrm{H}_{2} \mathrm{P}_{2} \mathrm{O}_{6}(\mathrm{ADhP})$. Chem. Mater. 2011, 23, 1082-1084. [CrossRef]

34. Medycki, W.; Latanowicz, L.; Szklarz, P.; Jakubas, R. Proton dynamics at low and high temperatures in a novel ferroelectric diammonium hypodiphosphate $\left(\mathrm{NH}_{4}\right)_{2} \mathrm{H}_{2} \mathrm{P}_{2} \mathrm{O}_{6}(\mathrm{ADhP})$ as studied by ${ }^{1} \mathrm{H}$ spin-lattice relaxation time and second moment of NMR line. J. Magn. Reson. 2013, 231, 54-60. [CrossRef] [PubMed]

35. Szklarz, P.; Przesławski, J.; Kosturek, B.; Jakubas, R. Phase transition of the novel hydrogen bonded ferroelectric $\left(\mathrm{NH}_{4}\right)_{2} \mathrm{H}_{2} \mathrm{P}_{2} \mathrm{O}_{6}$ studied by specific heat measurements. Thermochim. Acta 2012, 527, 8-12. [CrossRef]

36. Kers, A.; Kers, I.; Stawiński, J.; Sobkowski, M.; Kraszewski, A. Studies on aryl H-phosphonates. 3. Mechanistic investigations related to the disproportionation of diphenyl H-phosphonate under anhydrous basic conditions. Tetrahedron 1996, 52, 9931-9944. [CrossRef]

37. Baudler, M. Untersuchungen über Phosphorverbindungen II. Zur Kenntnis der Umsetzung von Dialkylphosphorsäurehalogeniden mit Natrium. Z. Naturforsch. 1954, 9b, 447-448. (In German) [CrossRef]

38. Baudler, M. Untersuchungen über Phosphorverbindungen. VII. Über die Ester der Unterphosphorsäure. Z. Anorg. Allg. Chem. 1956, 288, 171-192. (In German) [CrossRef]

39. Michalski, J.; Zwierzak, A. Synthesis of Tetraalkyl Hypophosphates. Bull. Acad. Polon. Sci. Ser. Sci. Chim. 1965, 13, $253-259$.

40. Stec, W.; Zwierzak, A. Cyclic organophosphorus compounds. II. Some sterically hindered cyclic hypophosphate systems and related compounds. Can. J. Chem. 1967, 45, 2513-2520. [CrossRef]

41. Stec, W.; Zwierzak, A.; Michalski, J. Studies on the Reaction of Dialkyl Phosphites with Dialkyl Phosphorochloridates in the Presence of Tertiary Amines. Bull. Acad. Pol. SciSer Sci. Chim. 1969, 17, 587-594.

42. Nycz, J.; Rachon, J. Reductive cleavage of the halogen—Phosphorus, oxygen-phosphorus and phosphorus-phosphorus bonds with alkali metals. Phosphorus Sulfur 2000, 161, 39-59. [CrossRef] 
43. Schab-Balcerzak, E.; Wiącek, M.; Nycz, J.; Kondratowicz, F. P-Winylobenzyle oraz Sposób ich Otrzymywania. Polski Patent P. 232855, 30 August 2019. (In Polish).

44. Kepler, J.A.; Carroll, F.I.; Garner, R.A.; Wall, M.E. Reaction of the Trichloromethyl Group with Di- and Trialkyl Phosphites. J. Org. Chem. 1966, 31, 105-107. [CrossRef]

45. Steinberg, G.M. Reactions of dialkyl phosphites. Synthesis of dialkyl chlorophosphates, tetraalkyl pyrophosphates, and mixed orthophosphate esters1. J. Org. Chem. 1950, 15, 637-647. [CrossRef]

46. Nylen, P. Studien uber Organische Phosphorverbindungen. Inaugural Dissertation, University of Uppsala, Uppsala, Sweden, 1930; pp. 62-64. (In German).

47. Arbuzov, A.E.; Arbuzov, B.A. Über die Ester der pyrophosphorigen, der Unterphosphor- und der Pyro-phosphorsäure, III. Mitteil.: Diäthyl- phosphorigsäure-chlorid und Darstellung von Tetraäthyl-pyrophosphit daraus. Berichte 1932, 65, 195-199. (In German)

48. Michalski, J.; Modro, T.; Zwierzak, A. Anhydrides of organophosphorus acids. Part II. The synthesis of tri- and tetra-alkyl esters of phosphorous phosphoric anhydride. J. Chem. Soc. 1961, 4904-4906. [CrossRef]

49. Michalski, J.; Zwierzak, A. A Novel Synthesis of Tetra-alkyl Hypophosphates. Proc. Chem. Soc. 1964, 80.

50. Mehrotra, R.C.; Srivastava, G.; Nagar, P.N. Dialkylphosphonate and Thiophosphonate (Open Chain and Cyclic) Derivatives of Arsenic(III) and Tin(IV). Phosphorus Sulfur 1983, 18, 145-148. [CrossRef]

51. Yin, Y.-W.; Chen, Y.; Zhao, Y.-F.; Li, L.-P. N-selective phosphorylation with chlorophosphoryl dialkylesters prepared from dialkylphosphite $/ \mathrm{CCl}_{4} / \mathrm{NEt}_{3}$. Phosphorus Sulfur 1993, 82, 67-72. [CrossRef]

52. Anderson, G.W.; Blodringer, J.; Welcher, A.D. Tetraethyl Pyrophosphite as a Reagent for Peptide Syntheses. J. Am. Chem. Soc. 1952, 74, 5309-5312. [CrossRef]

53. Anderson, G.W.; McGregor, A.C. t-Butyloxycarbonylamino Acids and Their Use in Peptide Synthesis. J. Am. Chem. Soc. 1957, 79, 6180-6183. [CrossRef]

54. Crofts, P.C.; Markes, J.H.H.; Rydon, H.N. Bis-o-phenylene Pyrophosphite: A New Reagent for Peptide Synthesis. Part I. The Preparation of Some o-Phenylene Pyrophosphites. J. Chem. Soc. 1958, 4250-4254. [CrossRef]

55. Arbuzov, B.A.; Nikonorov, K.W.; Fedorova, O.N.; Vinokurova, G.M.; Schischova, Z.G. Glikolevye efiry pirofosforistoi kisloty. Doklady Akad. Nauk SSSR 1953, 91, 817-820. (In Russian)

56. Foss, W.L.; Lukashev, N.W.; Lutsenko, I.F. Tetraamidodiphosphine monoxides and isomeric diamidophosphoric acid anhydrides phosphorotropic tautomerism of these compounds. Zh. Obshch. Khim. 1980, 50, 1236-1246. (In Russian)

57. Foss, W.L.; Lukashev, N.W.; Petrovsky, P.W.; Lutsenko, I.F. Unsymmetrical amidoalkoxydiphosphine monoxides and their isomeric mixed anhydrides-phosphorotropic tautomerism. Zh. Obshch. Khim. 1980, 50, 2400-2409. (In Russian)

58. Foss, W.L.; Kudinova, W.W.; Lutsenko, I.F. Synthesis and isomerization of mixed anhydrides of phosphorus and phosphonic-acids. Zh. Obshch. Khim. 1984, 54, 545-552. (In Russian)

59. Foss, W.L.; Kudinova, W.W.; Lutsenko, I.F. Reversible isomerization of mono-oxidized alkyltrialkoxydiphosphines. Zh. Obshch Khim. 1980, 50, 2803-2805. (In Russian)

60. Konovalova, I.W.; Ofitserov, E.N.; Mironov, W.F.; Kostyuk, W.I.; Pudovik, A.N. Reactions of pyrocatechintrifluoracylphosphite with alcohols and acids. Zh. Obshch. Khim. 1983, 53, 1945-1950. (In Russian)

61. Alfonsov, W.A.; Zamaletbinova, G.U.; Watyeva, E.S.; Pudovik, A.N. Reaction of diethyldithiochlorophosphite with silylphosphites and diethylphosphites. Zh. Obshch. Khim. 1985, 55, 704-705. (In Russian)

62. Nifantev, E.E.; Kukhareva, T.S.; Solbatova, I.A.; Tchukhvar, T.G. Cyclophosphites and amidophosphites of 3,5-di-tertbutylpyrocatechols. Zh. Obshch. Khim. 1986, 56, 2487-2491. (In Russian)

63. Rachoń, J. Fosforowe odczynniki nukleofilowe typu >P-O w reakcjach halofilowej substytucji. Wiadomości Chem. 2000, 54, 105-126. (In Polish)

64. Nifantev, E.E.; Grachev, M.K.; Bekker, A.R.; Wasyanina, L.K.; Koroteyev, A.M. Study of 2-(1-imidazolyl)-5,5-dimethyl-1,3,2dioxaphosphorinane. Zh. Obshch. Khim. 1988, 58, 312-316. (In Russian)

65. Winter, N.J.; Fossey, J.; Beccard, B.; Berchadsky, Y.; Vila, F.; Werbelow, L.; Tordo, P. Kinetic and Spectroscopic Characterization of the Diarylphosphonyl Radical, $\left(2,4,6-\mathrm{Bu}_{3}{ }_{3} \mathrm{C}_{6} \mathrm{H}_{2}\right)_{2} \mathrm{P}=\mathrm{O}$. J. Phys. Chem. 1986, 90, 6749-6750. [CrossRef]

66. Leca, D.; Fensterbank, L.; Lacôte, E.; Malacria, M. Recent advances in the use of phosphorus-centered radicals in organic chemistry. Chem. Soc. Rev. 2005, 34, 858-865. [CrossRef] [PubMed]

67. Romakhin, A.S.; Zagumennov, V.A.; Nikitin, E.V. Electrochemical oxidation and interaction with salt halogens of dialkyl phosphorus acids. Russ. J. Gen. Chem. 1997, 67, 7, 1085-1090. (In Russian)

68. Nycz, J.E.; Musiol, R. New approaches to the synthesis of diphosphine dioxides and hypophosphoric acid esters. Heteroatom Chem. 2006, 17, 310-316. [CrossRef]

69. Zhou, Y.; Yin, S.; Gao, Y.; Zhao, Y.; Goto, M.; Han, L.-B. Selective PP and POP Bond Formations through Copper-Catalyzed Aerobic Oxidative Dehydrogenative Couplings of H-Phosphonates. Angew. Chem. Int. Ed. 2010, 49, 6852-6855. [CrossRef]

70. Nycz, J.E.; Malecki, G.; Chikkali, S.; Hajdok, I.; Singh, P. The Reaction of Quinoline-5,8-diones With Selected Charged Phosphorus Nucleophiles. Phosphorus Sulfur 2012, 187, 564-572. [CrossRef]

71. Bunnett, J.F. Aromatic Substitution by the SRN1 Mechanism. Acc. Chem. Res. 1978, 11, 413-420. [CrossRef]

72. Russell, G.A.; Hershberger, J. Trapping of radicals by dialkyl phosphite ions; synthesis of $\alpha$-nitroalkylphosphonates by $S_{\mathrm{RN}} 1$ reactions. J. Chem. Soc. Chem. Commun. 1980, 216-217. [CrossRef] 
73. Haynes, R.K.; Lam, W.W.-L.; Williams, I.D.; Yeung, L.-L. The First Examples of Enantiomerically Pure Diphosphane Dioxides- $\left(R_{P}, R_{P}\right)$ - and $\left(S_{P}, S_{P}\right)$-1,2-Di-ter-butyl-1,2-diphenyldiphosphane 1,2-Dioxides, and $\left(R_{P}\right)$ - and $\left(S_{P}\right)$-1-tert-Butyl-1,2,2triphenyldiphosphane 1,2-Dioxides. Chem. Eur. J. 1997, 3, 2052-2057. [CrossRef]

74. Hitchcock, P.B.; Lappert, M.F.; Nycz, J.E. Synthesis, structure and reductive dechlorination of the C-centered phosphorus(III) $\beta$-diketiminate $\mathrm{PCl}(\mathrm{Ph}) \mathrm{L}\left[\mathrm{L}=\mathrm{C}\left\{\mathrm{C}(\mathrm{Me}) \mathrm{NC}_{6} \mathrm{H}_{3} \operatorname{Pr}^{\mathrm{i}}{ }_{2}-2,6\right\}\left\{\mathrm{C}(\mathrm{Me}) \mathrm{NHC}_{6} \mathrm{H}_{3} \operatorname{Pr}_{2}{ }_{2}-2,6\right\}\right]$. Chem. Commun. 2003, 10, 1142-1143. [CrossRef]

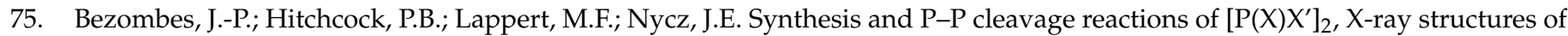
$\left[\mathrm{Co}\left\{\mathrm{P}(\mathrm{X}) \mathrm{X}^{\prime}\right\}(\mathrm{CO})_{3}\right]$ and $\mathrm{P}_{4}\left[\mathrm{P}(\mathrm{X}) \mathrm{X}^{\prime}\right]_{2}\left[\mathrm{X}=\mathrm{N}\left(\mathrm{SiMe}_{3}\right)_{2}, \mathrm{X}^{\prime}=\mathrm{NPr}^{\mathrm{i}}{ }_{2}\right]$. Dalton Trans. 2004, 4, 499-501. [CrossRef] [PubMed]

76. Bezombes, J.-P.; Borisenko, K.B.; Hitchcock, P.B.; Lappert, M.F.; Nycz, J.E.; Rankin, D.W.H.; Robertson, H.E. Structures of the radical $\mathrm{P}\left[\mathrm{N}\left(\mathrm{SiMe}_{3}\right)_{2}\right]\left(\mathrm{NPr}_{2}{ }_{2}\right)$, its dimer, cation and chloro derivative. Dalton Trans. 2004, 13, 1980-1988. [CrossRef] [PubMed]

77. Eichbichler, J.; Peringer, P. (O-n-Butyl-P-phenyl-phosphonito-P)-Mercury Complexes. Inorg. Chim. Acta 1980, 43, 121-124. [CrossRef]

78. Peringer, P.; Eichbichler, J. Bis(di-tert-butylphosphinito-P)mercury. Preparation and properties. J. Inorg. Nucl. Chem. 1981, 43, 2033-2036. [CrossRef]

79. Nycz, J.E. Synthetic and Mechanistic Aspects of Preparation of Phosphinito and Phosphito-mercuries. Heteroatom Chem. 2008, 19, 234-237. [CrossRef]

80. Germann, F.E.E.; Traxler, R.N. Preparation and melting points of pure di- and triiodide of phosphorus. J. Am. Chem. Soc. 1927, 49, 307-312. [CrossRef]

81. Hewertson, W.; Watson, H.R. The Preparation of Di- and Tri-tertiary Phosphines. J. Chem. Soc. 1962, 1490-1494. [CrossRef]

82. Kuchen, W.; Buchwald, H. Mono- und Oligophenylphosphine. Angew. Chem. 1956, 68, 791. (In German) [CrossRef]

83. Issleib, K.; Seidel, W. Darstellung und chemisches Verhalten aliphatischer und cycloaliphatischer Diphosphine, $\mathrm{R}_{2} \mathrm{P}-\mathrm{PR} 2$. Chem . Ber. 1959, 92, 2681-2694. (In German) [CrossRef]

84. Kuchen, W.; Buchwald, H. Zur Kenntnis der Organophosphorverbindungen, II. Das Tetraphenyldiphosphin. Chem. Ber. 1958, 91, 2871-2877. (In German) [CrossRef]

85. Issleib, K.; Hoffmann, M. Alkali-Phosphorverbindungen und ihr reaktives Verhalten, XLI. Tetra-tert.-butyl-biphosphin und Tetra-tert.-butyl-cyclotetra-phosphin. Chem. Ber. 1966, 99, 1320-1324. (In German) [CrossRef]

86. Niebergall, H. Synthese von Tetraorgano-diphosphinen und Diorgano-phosphinen. Angew. Chem. 1960, 72, 210. (In German) [CrossRef]

87. Hart, F.A.; Mann, F.G. The Synthesis and Properties of 4-Methyl-o-phenylenebis-(diethylphosphine). J. Chem. Soc. 1957, 39393944. [CrossRef]

88. Fild, M.; Hollenberg, I.; Glemser, O. Reaktionen der Pentafluorphenyl-phosphorhalogenide. Naturwissenschaften 1967, 54, 89-90. (in German). [CrossRef]

89. Horner, L.; Dickerhof, K. Studien zum Vorgang der Wasserstoffübertragung, 67. Endioldiester durch acylierende elektroreduktive Dimerisierung von Carbonsäurechloriden mit Lithiumamalgam. Chem. Ber. 1983, 116, 1603-1614. (In German) [CrossRef]

90. Homer, L.; Beck, P.; Hoffmann, H. Phosphororganische Verbindungen, XIX. Reduktion von Phosphorverbindungen mit Alkalimetallen. Chem. Ber. 1959, 92, 2088-2094. (In German)

91. Goda, K.; Gomi, H.; Yoshifuji, M.; Inamoto, N. Metal Phosphinylides and Phosphinothioylides. VII. The Structure of [Ph 2 PX]M $(\mathrm{X}=\mathrm{O}, \mathrm{S})$ in Solution and Their Disproportionation. Bull. Chem. Soc. Jpn. 1977, 50, 545-546. [CrossRef]

92. Sasaki, M.; Collin, J.; Kagan, H.B. Reactions of P-Cl Compounds in presence of SmI 2 . Tetrahedron Lett. 1991, 32, 2493-2496. [CrossRef]

93. Stankiewicz, M.; Nycz, J.; Rachon, J. Reductive cleavage of the halogen-phosphorus and sulfur-phosphorus bonds with alkali metals. Heteroatom Chem. 2002, 13, 330-339. [CrossRef]

94. Hunter, D.; Michie, J.K.; Miller, J.A.; Stewart, W. The reaction of diphenylphosphine oxide with diphenylphosphinous chloride in the absence of base. Phosphorus Sulfur 1981, 10, 267-270. [CrossRef]

95. Aksnes, G.; Majewski, P. Investigation of the reaction between dialkylphosphine oxides and carbontetrachloride. Phosphorus Sulfur 1986, 26, 261-274. [CrossRef]

96. Quin, L.D.; Anderson, H.G. Some New Reactions of Functions Containing Secondary Phosphorus. J. Org. Chem. 1966, 31, 1206-1209. [CrossRef]

97. Pearson, R.G. Hard and Soft Acids and Bases. J. Am. Chem. Soc. 1963, 85, 3533-3539. [CrossRef]

98. Foss, W.L.; Kudinova, P.L.; Lutsenko, I.F. Effect of spatial barriers on the relative thermodynamical stability of monooxides of trialkylalkoxy diphosphines and isomeric anhydrides. Zh. Obshch. Khim. 1983, 53, 2193-2199. (In Russian)

99. Rose, M.G.; Farrell, M.P.; Schmitz, J.C. Thymidylate Synthase: A Critical Target for Cancer Chemotherapy. Clin. Colorectal Canc. 2002, 1, 220-229. [CrossRef]

100. Setondji, J.; Remy, P.; Ebel, J.-P.; Dirheimer, G. Analogues de nucléosides polyphosphates. V. Action de l'adfnosine-5'hypophosphate sur l'adénylate kinase et la pyruvate kinase. Préparation de l'adénosine-5'-hypophosphophosphate, analogue structural de l'ATP. Biochim. Biophys. Acta 1971, 232, 585-594. (In French) [CrossRef]

101. Setondji, J.; Remy, P.; Dirheimer, G.; Ebel, J.-P. Analogues de nucleosides polyphosphate IV. Synthese de l'adenosine 5'hypophosphate un analogue structural de L'ADP. Biochim. Biophys. Acta 1970, 224, 136-143. (In French) [CrossRef] 